Illinois State University

ISU ReD: Research and eData

Theses and Dissertations

$10-29-2018$

\title{
After Faith, Hope, and Love: The Unique Divergence of Asceticism by Gregory the Great and Maximus the Confessor
}

Caleb N. Zuiderveen

Illinois State University, kalebahzuider@gmail.com

Follow this and additional works at: https://ir.library.illinoisstate.edu/etd

Part of the European History Commons, History of Religion Commons, Medieval History Commons, and the Religion Commons

\section{Recommended Citation}

Zuiderveen, Caleb N., "After Faith, Hope, and Love: The Unique Divergence of Asceticism by Gregory the Great and Maximus the Confessor" (2018). Theses and Dissertations. 1024.

https://ir.library.illinoisstate.edu/etd/1024

This Thesis is brought to you for free and open access by ISU ReD: Research and eData. It has been accepted for inclusion in Theses and Dissertations by an authorized administrator of ISU ReD: Research and eData. For more information, please contact ISUReD@ilstu.edu. 


\section{AFTER FAITH, HOPE, AND LOVE: THE UNIQUE DIVERGENCE OF ASCETICISM BY GREGORY THE GREAT AND MAXIMUS THE CONFESSOR}

\section{CALEB N. ZUIDERVEEN}

\section{Pages}

In the late sixth and early seventh centuries, asceticism continued as a frequent expression of Christian devotion. Despite communications between the Eastern and Western Churches and a common patristic foundation, theology in the East and West during this time diverged on the results of asceticism. This paper explores this divergence by examining two theologians, Gregory the Great and Maximus the Confessor. Current scholarship has examined Gregory the Great and Maximus the Confessor on their own, yet the dialogue between each tradition and its implications remains understudied. Thus, this study contextualizes Gregory the Great's On the Song of Songs and Maximus the Confessor's Letter 2: On Love. Though both agreed on asceticism's importance, they described its outcome differently. Gregory viewed asceticism's result as a fuller, but imperfect, knowledge of God, while Maximus saw human deification as its result. While both authors used similar theological traditions, certain theologians, like Pseudo-Dionysus and Augustine, were only used by one author or the other. Because of Maximus' doctrine of deification, holy men could be revered in the East. Yet, Gregory saw man as imperfect until after death; thus, it was more acceptable to revere relics in the West. Ultimately, grasping this divergence helps explain the Holy Man in the East and West. KEYWORDS: Christianity; Deification; Gregory the Great; Maximus the Confessor; Late Antiquity; Mysticism 


\title{
AFTER FAITH, HOPE, AND LOVE: THE UNIQUE DIVERGENCE OF ASCETICISM BY GREGORY THE GREAT AND MAXIMUS THE CONFESSOR
}

\author{
CALEB N. ZUIDERVEEN
}

\author{
A Thesis Submitted in Partial \\ Fulfillment of the Requirements \\ for the Degree of \\ MASTER OF ARTS \\ Department of History \\ ILLINOIS STATE UNIVERSITY
}


Copyright 2018 Caleb N. Zuiderveen 


\section{AFTER FAITH, HOPE, AND LOVE: THE UNIQUE DIVERGENCE OF ASCETICISM BY GREGORY THE GREAT AND MAXIMUS THE CONFESSOR}

CALEB N. ZUIDERVEEN

COMMITTEE MEMBERS:

Kathryn Jasper, Chair

Georgia Tsouvala 


\section{CONTENTS}

Page

CONTENTS

INTRODUCTION: THE TALE OF TWO THEOLOGIANS

CHAPTER I: GREGORY THE GREAT: LOOKING EAST BUT WALKING WEST

CHAPTER II: MAXIMUS THE CONFESSOR: TO DEIFICATION WITH LOVE 


\section{INTRODUCTION: THE TALE OF TWO THEOLOGIANS}

The late sixth and early seventh centuries were a time of massive change for the Mediterranean. Migrating Germanic tribes expanded into lands that were once part of the Western Roman Empire. Although many of these tribes earlier were hospites of the Roman Empire, and thereby allowed to settle on Roman land, with the decline of the political power of Rome, many of these tribes gained political control over these regions and divided up the former Western Roman Empire into local kingdoms. Other migrating tribes, like the Lombards, moved into the area later, having to sometimes forcefully establish their presence in the area. To citizens of both the former Western Roman Empire and the Eastern Roman Empire, these migrations looked like invasions that threatened the Roman rule. By the sixth century, Lombards surrounded Rome itself. Although the Eastern Roman Empire under Justinian had tried to reclaim the Western half of the Empire from these tribes, the combination of resistance from the Lombards, plague, and the need to defend his own borders meant that this dream would never be fully realized. Furthermore, the Sassanid Empire in Persia threatened the southeastern border of the Eastern Roman Empire.

While these major events of human conflict alone would be cause for change across the Mediterranean, other events also helped contribute to the chaos of this time period. Plague was one major occurrence that scared much of the Mediterranean world. Ever since the Justinianic Plague spread from Egypt to the rest of the Mediterranean, the bubonic plague had been a recurring pestilence around the former Roman Empire. ${ }^{1}$ In $590 \mathrm{CE}$, a certain outbreak of plague extended throughout Italy, killing not only many commoners but also killing Pope Pelagius II. ${ }^{2}$ Other environmental concerns also beset Italy, including unusual flooding which not only

\footnotetext{
${ }^{1}$ Bryan Ward-Perkins, The Fall of Rome and the End of Civilization, (Oxford: Oxford University Press, 2006), 133.

${ }^{2}$ Mark DelCogliano, "Introduction," Gregory the Great: On the Song of Songs (Collegeville, MN: Cistercian Publications, 2012), 14.
} 
flooded Rome but also submerged granaries important to supplying Rome with food for its population. $^{3}$

In addition to the natural disasters that were occurring in Rome and throughout the Mediterranean, there were theological crises in the Eastern Roman Empire. One of the major disputes raging was that over the will of Christ. Some theologians argued that Christ had only one will and one nature, first expressed in the Monophysites, while others stated that Christ had two wills and natures, one human and one divine. ${ }^{4}$ This doctrine would later be named dyothelitism. The term "will" represented the process of inward thought that made people act in certain ways. The argument that Christ had one will while on the earth meant that His decisions were solely driven by the thoughts and desires of his divinity. On the other hand, dyothelitism taught that Christ had both human and divine desires which conflicted with each other, best seen in the Garden of Gethsemane.

As a result of the disagreement over the will of Christ, there were major controversies in the church of the Eastern Roman Empire with those in Constantinople wanting to silence the dissension. Consequently, emperor Herakleios in his ekthesis of 638 not only forbade the discussion of the will of Jesus but also endorsed a theological compromise: Monothelitism. ${ }^{5}$ This doctrine stated that Jesus was one person with a human and divine nature; however, He only had a divine will. ${ }^{6}$ Unfortunately, this official compromise on the will of Jesus would not calm the theological storm in the Byzantine Empire and this theological division would continue.

\footnotetext{
${ }^{3}$ DelCogliano, "Introduction," 14.

${ }^{4}$ Andrew Louth, "Introduction," in Maximus the Confessor, trans. and ed. Andrew Louth, (New York: Routledge, 2006), 48.

${ }^{5}$ Andrew Louth, "Christology and Heresy," A Companion to Byzantium, ed. Liz James (Malden, MA: Blackwell Publishing, 2010), 195.

${ }^{6}$ Louth, "Christology and Heresy," 195.
} 
Because of this chaos, I thought that it would be interesting to study the transfer of theological ideas of the Church during this time period. It would be a misnomer to say that a unified Church existed during this time. The fact of this disunity not only is seen in the conflict between the will of Christ, but it also can be witnessed in other factions that appeared over the course of Late Antiquity. Some of these factions that were declared heresy include Arianism and Pelagianism. However, the Schism of the Three Chapters in Northern Italy showed that even among "orthodox" Christian churches, there were great differences in theological thought.

Despite this fragmentation, there was also interconnectivity among the churches during Late Antiquity. ${ }^{7}$ For example, Gregory the Great sent letters throughout the Mediterranean, to people including Emperor Maurice of the Eastern Roman Empire and the patriarch of Antioch. In these letters Gregory discussed theological ideas like the meaning behind the title of the pope and the pope's role in Christianity. ${ }^{8}$ These were not one-way communications, and Gregory often received responses to his theological inquiries. ${ }^{9}$ Because of this interconnectivity around the Mediterranean, in spite of the chaos around the Church, I wanted to see the extent to which theological ideas transferred from the Eastern theological tradition to the West and vice versa. To do this examination, I decided to look at two specific theologians, one from the Western tradition, Gregory the Great, and another from the Eastern tradition, Maximus the Confessor, examine their theological continuities and differences, and see what that could reveal about the transfer of theological information during the time. This kind of comparison of theology and mystical beliefs between theologians in the East and West has not been heavily done in the historiography of either Maximus or Gregory, and thus this study will help give historians a

\footnotetext{
${ }^{7}$ Peter Brown, The Rise of Western Christendom, (Malden, MA: Blackwell Publishing, 2003), 12.

${ }^{8}$ George E. Demacopoulos, The Invention of Peter: Apostolic Discourse and Papal Authority in Late Antiquity, (Philadelphia: University of Pennsylvania Press, 2013), 153-4.

${ }^{9}$ Demacopoulos, The Invention of Peter, 154.
} 
better picture the ways in which theological ideas are transmitted across the Mediterranean.

When using monographs and other secondary sources to research for this study, they will be limited to English sources.

This study, first, will examine the theology of Gregory the Great. He is a good theologian to study because, first, his importance to medieval religious thought. The writings of Gregory would be central to medieval thought, especially during and after the rule of the Carolingians. Furthermore, Gregory was well-traveled, living not only in Rome but also living part of his life in Constantinople as a papal representative. ${ }^{10}$ Finally, Gregory is great for this study because of his extensive writings. He had written many letters to people throughout the Mediterranean. Moreover, his Regula Pastoralis would be important to the practice of the clergy not only in the West but also in the East. ${ }^{11}$ In his writings, Gregory showed influences not only from Western theologians but also from theologians located in the Eastern theological tradition. ${ }^{12}$

There have been multiple monographs, chapters, and articles that have been written about the theological thought of this pontiff. In the early twentieth century, theological scholar F. Homes Dudden wrote two volumes on Gregory and while Dudden said that he was influential to medieval thought, he also argued that the pope was not an innovative theologian, borrowing most of his "good" ideas from previous theologians. ${ }^{13}$ After the mid century, new studies on Gregory found him to be an innovative thinker, taking ideas from previous theologians and altering them. For example, historian Beryl Smalley in his book The Study of the Bible in the Middle Ages

\footnotetext{
${ }^{10}$ Brown, The Rise of Western Christendom, 201.

${ }^{11}$ DelCogliano, "Introduction," 22.

${ }^{12}$ Brown, The Rise of Western Christendom, 203.

${ }^{13}$ F. Homes Dudden, Gregory the Great: His Place in History and Thought Volume Two, (London: Longmans, Green, and Co., 1905), 286.
} 
would praise the pontiff in the introduction, stating that through adapting and expanding previous theological ideas, that he displayed his originality. ${ }^{14}$

This would be furthered in the late eighties, when Carole Straw wrote the monograph, Gregory the Great: Perfection in Imperfection. In the book, Straw argues that Gregory the Great, while borrowing earlier theologian's ideas, reworked these ideas into a unique theology containing a unique paradoxical structure emphasizing certain oppositions. ${ }^{15}$ In 1996, Late Antique historian Peter Brown would write a chapter on Gregory the Great in his book, The Rise of Western Christendom. While he noted the centrality of the pontiff both politically and religiously, Brown argued that although Gregory drew upon the theological foundations of Augustine, especially in his Regula Pastoralis, he was not merely an imitator. ${ }^{16}$ Instead, Brown argued that Gregory combined Augustinian theology with real examples of a pastor's life. ${ }^{17}$ In the 2000s, other works appeared that examined Gregory the Great. One important work, A Companion to Gregory the Great, was composed in 2013 and contained sixteen articles examining the life, theology, writing, and reception of Gregory the Great. Very recently, in 2015, historian George E. Demacopoulus wrote a monograph on the pontiff, Gregory the Great: Ascetic Pastor, and First Man of Rome. In the book, he shows how Gregory's theology, both ascetic and pastoral, informed his administration of the Catholic Church. ${ }^{18}$ In the first chapter he compares Gregory's theology to fabric, saying that in his works “we find an embroidery of many ascetic threads..." all which enforce a unique social dimension of asceticism. ${ }^{19}$

\footnotetext{
${ }^{14}$ Beryl Smalley, The Study of the Bible in the Middle Ages, (Notre Dame, IN: Notre Dame University Press, 1978), 32.

${ }^{15}$ Carole Straw, Gregory the Great: Perfection in Imperfection, (Berkeley: University of California Press, 1988$), 13$.

${ }^{16}$ Brown, The Rise of Western Christendom, 209.

${ }^{17}$ Brown, The Rise of Western Christendom, 209.

${ }^{18}$ George E. Demacopoulos, Gregory the Great: Ascetic, Pastor, and First Man of Rome. Notre Dame, IN: University of Notre Dame Press, 2015. Kindle Edition, Kindle Location 259-260.

${ }^{19}$ Demacopoulos, Gregory the Great, Kindle Location 363.
} 
However, in all these works, there is little to be said about Gregory's On the Song of Songs. General monographs like those of Peter Brown do not mention the work at all, and even Demacopoulus' work does not talk about it. Carol Straw briefly uses the work, but only in passing, when trying to explain church structure and the Incarnation of Christ. ${ }^{20}$ There were a few books that did deal with this work. Barnard McGinn in the Gregory the Great chapter of The Growth of Mysticism: Gregory the Great to the $12^{\text {th }}$ Century, regularly referenced the commentary and its influence on Gregory's mysticism, even stating that the influence of the Song of Songs influenced Gregory's ideas of union with God. ${ }^{21}$ E. Ann Matter, in The Voice of My Beloved: The Song of Songs in Western Medieval Christianity, explains the importance of Gregory's commentary to medieval monasticism and the view of the Church during and after his papacy arguing that in the work he shows the Church as a mystical organization with potential for corruption but applauding the ideals of the monastic life. ${ }^{22}$ In 2012, Mark DelCogliano translated Gregory's On the Song of Songs into English. In the introduction he analyzed its significance not only historically, but also theologically. While these analyses are helpful, he only explains certain sections of the text, leaving room for other historians to expand.

Therefore, because this source has not been greatly studied by historians, this study will examine Gregory the Great's commentary On the Song of Songs. Specifically, the study will mainly focus on Gregory's allegory of the house and his warning of humility, connecting the ideas of that specific section to Gregory's overall theology and mysticism. In addition, other sections of the work will be examined to further help show the importance of certain theologians to the writings of Gregory. This study examines On the Song of Songs because the inspiration

\footnotetext{
${ }^{20}$ Straw, Gregory the Great, 171, 253.

${ }^{21}$ Bernard McGinn, The Growth of Mysticism: Gregory the Great to the $12^{\text {th }}$ Century, (New York: The Crossroad Publishing Company, 1994), 70.

22 E. Ann Matter, The Voice of My Beloved: The Song of Songs in Western Medieval Christianity, (Philadelphia: University of Philadelphia Press, 1992), 95-96.
} 
behind much of Gregory's theology can be seen in this relatively small work. Ideas of theologians like Augustine and Cassian are blended with Origen and other Eastern sources creating a theology unique to Gregory. ${ }^{23}$

Similarly, this study examines Maximus the Confessor because of his influence on the theological thought of the East. While Maximus is best known for his defending dythelitism against monophysites and monothelitism in the churches in the Eastern Roman Empire, he also helped interpret Eastern Church theologians including the Cappadocian Fathers and PseudoDionysus. ${ }^{24}$ Because of this Historian John Mayandorff called Maximus the "real father of Byzantine theology." ${ }^{25}$ Furthermore, his writings were also heavily influential in the West during the ninth century when Scotus Erigena, an Irish monk who read Greek in addition to Latin, used Maximus' theology in his own thought and translated some of Maximus' works into Latin. ${ }^{26}$ Maximus is also a good theologian to study in the context of theological transmission because of his travels. With the Persian invasion of the Eastern Roman Empire, Maximus the Confessor fled to North Africa and Italy, places heavily influenced by Western theologians like Augustine and Ambrose. Consequently, because of his travels, he would have had a good chance of learning Western theology in his thought and writings.

The historiography of the modern study of Maximus the Confessor is neatly laid out in Joshua Lollar's article "Reception of Maximian Thought in the Modern Era." He specifically delves into writers who wrote important monographs on Maximus including Sergei Leotevich Epifanovich, Hans Urs von Balthasar, Polycarp Sherwood, Walther Völker, and Lars

\footnotetext{
${ }^{23}$ DelCogliano, "Introduction," 85.

${ }^{24}$ Pauline Allen, "Life and Times of Maximus the Confessor," in The Oxford Handbook of Maximus the Confessor ed. Pauline Allen and Bronwen Neil, (Oxford: Oxford University Press, 2015), 9-10.

${ }_{25}$ John Meyendorff, Byzantine Theology, (New York: Fordham University Press, 1974$), 37$.

${ }^{26}$ McGinn, The Growth of Mysticism, 92.
} 
Thunberg. ${ }^{27}$ Afterwards, he does briefly mention some of the historians working on Maximus the Confessor after Thunberg noting their last names and the topics of their works. ${ }^{28}$ Some of these historians who were either mentioned briefly or not mentioned at all in Lollar's work and who are important to this study are Paul Blowers, Andrew Louth, Adam Cooper, and Norman Russell.

In 1991, Paul Blowers wrote a monograph on Maximus the Confessor's Biblical exegesis, specifically looking into Maximus' Quaestiones ad Thalassium. He specifically wanted to explain how Maximus combined spiritual pedagogy and exegesis. ${ }^{29} \mathrm{He}$ wrote it as a response to historians who would cite parts of Quaestiones ad Thalassium instead of examining it on its own merits. ${ }^{30}$ Understanding of Maximus would be furthered in 1996, Andrew Louth translated some of Maximus the Confessor's works into English, including Maximus' Letter 2: On Love. However, before this, Louth gives a general introduction to the history of Maximus the Confessor and his theology. While his history section is outdated and based on the history put together by Polycarp Sherwood in the 1950s, as will become evident in the second chapter, Louth does a good job of showing how Maximus blends both patristic theology and Proclean Neo-Platonism. ${ }^{31}$

In 2005, Adam Cooper would write a monograph, The Body in St. Maximus the Confessor: Holy Flesh, Wholly Deified. In it, he fills the gap in Maximus the Confessor's historiography which failed to address the role of the body in the writings of Maximus. ${ }^{32}$ While he does not take modern issues about the body that were posited by anthropological and gender

\footnotetext{
${ }^{27}$ Joshua Lollar, "Reception of Maximian Thought in the Modern Era," in The Oxford Handbook of Maximus the Confessor ed. Pauline Allen and Bronwen Neil, (Oxford: Oxford University Press, 2015), 564.

${ }^{28}$ Lollar, "Reception of Maximian Thought," 576-577.

${ }^{29}$ Paul M. Blowers, Exegesis and Spiritual Pedagogy in Maximus the Confessor: An Investigation of the

"Quaestiones ad Thalassium," (Notre Dame, IN: University of Notre Dame Press, 1991), 15.

${ }^{30}$ Blowers, Exegesis and Spiritual Pedagogy, 14.

${ }^{31}$ Louth, "Introduction," 19.

32 Adam G. Cooper, The Body in St. Maximus the Confessor: Holy Flesh, Wholly Deified, (Oxford: Oxford University Press, 2005), 15.
} 
studies scholars, he does look at it theologically and its role in the deification of a Christian. ${ }^{33}$ Finally, while not writing a monograph solely about Maximus, Norman Russell's 2006 study on deification, The Doctrine of Deification in the Greek Patristic Tradition, adds Maximus the Confessor to the end of his study on deification, whereas the author of the previous major study on deification, Jules Gross, had ended his study on John Damascene. ${ }^{34}$

In this historiography there are few historians who have deeply looked at Maximus' Letter 2: On Love. It is in this gap in the study of Maximus the Confessor which this study will help expand. This letter, an exhortation to John the Cubicularius to continue in the virtue of love, gives an overview of Maximus' views on love, its corruption, and humanity's ability to be deified. Through his explanation of these themes in the letter, Maximus reveals the Eastern influences in his theological thought.

In addition to the lack of historical study on Gregory the Great's On the Song of Songs and Maximus the Confessor's Letter 2: On Love, this study uses these sources because both have sections that expound upon the same Biblical passage: 1 Corinthians 13:13. Both theologians expand upon the ideas of faith, hope, and love, not just as virtues but as markers of Christian advancement in holiness. Furthermore, both Maximus and Gregory examinations on 1 Corinthians 13 go beyond the pursuit of virtue, also emphasizing the pursuit of Christian mysticism. Because of these similar features, I thought that these two sources would be good to compare the mysticism of Gregory with that of Maximus.

One cause of concern for some historians about this study will be the comparison between the theological ideas of the East and the West. Recent historians have shied away from these distinctions, especially when looking at Gregory the Great. In 2013, in the article, "Gregory

\footnotetext{
${ }^{33}$ Cooper, The Body in St. Maximus the Confessor, 15-16.

${ }^{34}$ Norman Russell, The Doctrine of Deification in the Greek Patristic Tradition, (Oxford: Oxford University Press, 2006), 8 .
} 
and the Greek East," historian Phil Booth hesitated to equate the language troubles of Gregory the Great to the narrative of the fragmentation of the East and the West, noting the extensive communications that Gregory still continued in the East. ${ }^{35}$ Similarly, in 2015, George Demacopoulos wanted to back away from the idea of East and West, noting the vast range of Gregory's administration not only spanning the Italian peninsula but reaching across the Mediterranean. ${ }^{36}$

However, for this study the dichotomy between East and West is useful to denote differences in language, structure, and, most importantly, theological heritage between the Eastern theological tradition and that of the West. One of the most common ways that historians use this distinction is to compare the political structure of the dissolving Roman Empire. For example, Peter Heather used this distinction of East and West when narrating that the downfall of the Eastern Roman Empire to the Arabians would be similarly dramatic to that of its "western counterpart" in the previous century. ${ }^{37}$

One important distinction between the two sides is language. There is a great chasm of language understanding during this time period. Those in the East generally spoke Greek while those in the West spoke either Latin, as is the case with Gregory the Great, or one of the Germanic languages of the barbarians. There were very few people who were able to go between Greek and Latin and both Gregory and Maximus had to rely on translations of works that were not originally in their language. While one must heed Peter Brown's warning in Society and the Holy in Late Antiquity that this language gap alone cannot fully explain the divergence of East

\footnotetext{
${ }^{35}$ Phil Booth, "Gregory the Great and the Greek East," in A Companion to Gregory the Great, ed. Bronwen Neil and Matthew J. Del Santo, (Leiden, Netherlands: Koninklijke Brill NV, 2013), 111.

${ }^{36}$ Demacopoulos, Gregory the Great, Kindle Location 268.

${ }^{37}$ Peter Heather, Empires and Barbarians: The Fall of Rome and the Birth of Europe, (Oxford: Oxford University Press, 2009), 378.
} 
and West, the terminology East and West is still helpful in that it categorize language understanding. ${ }^{38}$

These comparisons are not solely used for political or linguistic comparisons. In fact, they are also used to distinguish traditions of Christian thought that were observed in either the East or the West. This kind of distinction can be seen in the work of Peter Brown, who in The Rise of Western Christendom, distinguishes between the two sides, most emphatically in the title of the second section of the book, "Divergent Legacies." 39 Throughout this section he compares the growing differences between the "Greek East" and "Latin West." 40 It is in this sense of theological distinction on which this study is going reflect when it refers to "East" and "West."

As will be noticeable further on in the study, Gregory the Great and Maximus the Confessor will be drawing ideas from certain theologians. While they both share some similar theological foundations, like the Desert Fathers, the ideas of some theologians will only be referenced by either Maximus or Gregory. These unique sources are localized to a certain traditions and, therefore, have important effects on each theologian's view of Christian mysticism. Consequently, this study will use the terms East and West primarily to emphasize the theological distinctions between Gregory and Maximus the Confessor.

There are a few other terms that need to be addressed before starting the analysis. Mysticism and deification will be used throughout the essay. Because of this, they need to be further explained in order to understand their meanings during this time period. The first of these is the concept of mysticism. While this word is undefined in many of the sources used, it may be beneficial to define the term in relation to Late Antique Christianity. Amy Hollywood, in her introduction to The Cambridge Companion to Christian Mysticism, gave a distinct definition of

\footnotetext{
${ }^{38}$ Peter Brown, Society and the Holy in Late Antiquity, (Berkeley, CA: University of California Press, 1982), 166.

${ }^{39}$ Brown, The Rise of Western Christendom, 143.

${ }^{40}$ Brown, The Rise of Western Christendom, 148-9.
} 
Christian mysticism that will be helpful for this study. In the section, she identifies that premodern "Christian mysticism can be best understood as a series of ongoing experiential, communal, and textual commentaries on and debates about the possibilities and limitations of encounters between God and humanity as they occur within history..." ${ }^{41}$ While the scope of the anthology gives little attention to the "Christian East" after the sixth century, her definition gives a good foundation for looking at both Gregory the Great and Maximus the Confessor's mysticism. ${ }^{42}$ Both will write about encounters between God and humanity not merely in terms of eschatology but also within the realm of human history. Gregory and Maximus will also describe the possibilities and limitations of divine encounters in their writings. Because of this, Amy Hollywood's definition fits the meaning of mysticism as it relates to the Christian, Late Antique tradition.

Deification is another term that will be constantly used throughout the study and must be examined. This idea of deification in general did not originate with Christianity; instead, deification was not unusual in the polytheistic Roman society. ${ }^{43}$ Mystery cults, the cult of the emperor, and imperial funeral rites all were all ways in which humans could be deified. ${ }^{44}$ The term would later be used by Jewish scholars, like Philo, who used Platonic ideas to help explain how the soul could ascend to God. ${ }^{45}$ In 160 CE, Christianity would take up the term, as Justin Martyr argued that the gods of Psalms 82:6 were Christians that practiced true obedience to Christ. ${ }^{46}$ Later, the word for deification, $\theta \varepsilon o \pi o l \varepsilon ́ \omega$, would be first used in a Christian context by

\footnotetext{
${ }^{41}$ Amy Hollywood, "Introduction," in The Cambridge Companion to Christian Mysticism, ed. Amy Hollywood and Patricia Z. Beckman, (Cambridge: Cambridge University Press, 2012), 7.

${ }^{42}$ Hollywood, "Introduction," 9.

${ }^{43}$ Russell, The Doctrine of Deification , 9.

${ }^{44}$ Russell, The Doctrine of Deification, 10.

${ }^{45}$ Russell, The Doctrine of Deification, 11.

${ }^{46}$ Russell, The Doctrine of Deification, 12.
} 
Clement of Alexandria to describe those who have detached themselves from the flesh through virtue and contemplation. ${ }^{47}$

After Clement used this term, it would constantly be redefined by future theologians in the East. While Origen posited that deification was participation with the divine, the Cappadocians thought that the doctrine meant the human sanctification towards likeness with God. ${ }^{48}$ However, the definition of deification in the Christian sense would solidify as a doctrine in the works of Pseudo-Dionysus and Maximus the Confessor. Pseudo-Dionysus emphasized the ascent of the soul and unity with God while Maximus the Confessor, while affirming the ideas of Pseudo-Dionysus, tried to understand how humans could participate with God in deification. ${ }^{49}$ Thus, to Maximus, deification involved the ascent of the soul towards unification with God, where humans might participate with the divine through the "interpenetration" of human and divine energy. ${ }^{50} \mathrm{~A}$ deeper explanation of this topic will be examined in the second chapter, where Maximus' theology and mysticism will be examined to a greater degree.

While this helps to explain the history of deification and its interpretation by Christian theologians, deification has been a topic of interest among the historical community. Much of the general historiography on the topic of deification has been discussed in Norman Russell's book The Doctrine of Deification in the Greek Patristic Tradition. In the book, Russell details both the religious and historical study into the doctrine of deification and the need for a deeper study into this particular doctrine. Particularly, he emphasizes the importance of Jules Gross' study on deification in the 1930s, both pointing out its central thesis that the doctrine of deification was Biblical rather than solely imported from Hellenistic thought and pointing out its many

\footnotetext{
${ }^{47}$ Russell, The Doctrine of Deification, 10, 12.

${ }^{48}$ Russell, The Doctrine of Deification, 12-13.

${ }^{49}$ Russell, The Doctrine of Deification, 14.

${ }^{50}$ Russell, The Doctrine of Deification, 14.
} 
weaknesses. ${ }^{51}$ Additionally, he points out some monographs that deal with deification by certain authors. ${ }^{52}$

The monograph of Norman Russell also contributed to this study of deification. This is primarily because it is the first overview of the subject since Gross' study. ${ }^{53}$ Because of this, he is able to incorporate more recent scholarship into his analysis. Additionally, Russell examined the Greek terminology used for deification in order to examine shifts in word usage over time and among different authors. ${ }^{54}$ Other studies that were not mentioned by Russell also have been influential in the study of deification. Adam Cooper's monograph that was mentioned above also was influential to the study of deification for it looked at the importance of the body to deification in three different aspects: Christ, the Church, and the Individual. ${ }^{55}$ Another article, written in 2015 by Jean-Caude Larchet called "The Mode of Deification," examined deification and how it changes man. In it, Larchet argued that while deification does not affect the logos of an individual, it does change a person's tropos, or mode.$^{56}$ This study is important as it not only examines "the mode of deification" but also it explains the result of deification and its effect on humanity. ${ }^{57}$

This examination into the mystical ideas of Gregory the Great and Maximus the Confessor will span three chapters. The first two chapters will look at the theological foundations of each author as shown in the context of Gregory's commentary and Maximus' letter, while the last chapter examines what both sources together can tell historians about the transmission of theological ideas during Late Antiquity. Specifically, the first chapter will examine Gregory the

\footnotetext{
${ }^{51}$ Russell, The Doctrine of Deification, 5-6.

${ }^{52}$ Russsell, The Doctrine of Deification, 6.

${ }^{53}$ Russell, The Doctrine of Deification, 7.

${ }^{54}$ Russell, The Doctrine of Deification, 8.

${ }^{55}$ Cooper, The Body in St. Maximus the Confessor, 15-16.

${ }^{56}$ Jean-Claude Larchet, "The Mode of Deification," in The Oxford Handbook of Maximus the Confessor ed. Pauline Allen and Bronwen Neil, (Oxford: Oxford University Press, 2015), 342-3.

${ }^{57}$ Larchet, "The Mode of Deification," 350-356.
} 
Great's commentary on the Song of Songs, putting it into historical context and arguing that although Gregory mysticism does borrow from Eastern sources, his interpretation stays within a Western framework. Therefore, Gregory, while looking East, was walking West. By looking at Gregory the Great's allegory of the house, one can see the role of faith, hope, and love in terms of the ascetic's rise in contemplation which leads to an experience with the divine in the King's bedchamber. ${ }^{58}$ While borrowing mystical elements from the Desert Fathers, particularly Origen, this Christian mysticism is restricted by warnings about man's nature that echo the words of Cassian and Augustine.

The second chapter will examine the letter of Maximus the Confessor. This chapter will argue that Maximus' mystical theology centered on the deification of Christians. In this letter, Maximus, too, uses faith, hope, and love as an example of the rise of the ascetic in contemplation. However, afterwards, Maximus states that the perfection of the love of God leads a Christian to "become God himself." 59 Maximus would employ the writings of PseudoDionysus and Proclean Neoplatonism, along with the Desert and Cappadocian Fathers, in order to flesh out the ultimate aim of Christian asceticism: deification.

In the final chapter I will put these two theologians in dialogue with each other in order to better understand the transmission of theological texts during this time period. In this section, I will argue that these works show that there was a limited transmission of theological texts between East and West. In other words, while some ideas were adopted on both sides, the stark difference in the descriptions of Christian mysticism points to ideas that Gregory or Maximus used that the other theologian either did not transfer or adopt.

\footnotetext{
${ }^{58}$ Gregory the Great, "Commentary on the Song of Songs," Gregory the Great: On the Song of Songs, trans. Mark DelCogliano (Collegeville, MN: Cistercian Publications, 2012), 128.

${ }^{59}$ Maximus the Confessor, "Letter 2: On Love," in Maximus the Confessor, trans. and ed. Andrew Louth, (New York: Routledge, 2006), 87.
} 
Not only will this section explain the theological transmission of information but it will also explore some reasons for these differences. I will posit that these differences can be explained through the theologians that were adopted by one and not the other, including Augustine and Pseudo-Dionysus. Additionally, this section will explain possible reasons that these ideas were not transferred between the two sides highlighting the problems related to language and theological focus.

The conclusion will examine the importance of this mystical dichotomy. Using Peter Brown's "The Rise and Function of the Holy Man," this section will show how this theological distinction between Gregory the Great and Maximus the Confessor helps to explain the distinction between the Eastern and Western holy man. In the article, Peter Brown explains that while Eastern churches praised living holy men, those in the Western Churches revered dead holy men. ${ }^{60}$ Specifically, because Peter Brown looked at this phenomenon from a social standpoint, Peter Brown barely addresses the theological reasoning behind the rise and functioning of the holy man in these different societies.

${ }^{60}$ Peter Brown, "The Rise and Function of the Holy Man in Late Antiquity," The Journal of Roman Studies 61 (1971), 100. 


\section{CHAPTER I: GREGORY THE GREAT: LOOKING EAST BUT WALKING WEST}

At the very end of the sixth century, Gregory the Great gave an oral lecture to students in Rome. ${ }^{61}$ The book of the Bible about which he lectured was not one to be taken lightly in Late Antiquity: The Song of Songs. With sexual acts viewed as inherently sinful and Gregory even saying in his Moralia that humankind is "conceived in sinful lust," he allegorically interpreted the Song of Songs. ${ }^{62}$ In the oration, Gregory likened the spiritual love between the Christian, or the Church in some cases, and Jesus Christ to the physical love as expressed in the Song of Songs. Consequently, Gregory's commentary used the book of the Bible in order to explain deeper theological concepts in the life of a Christian. In one section of this commentary, Gregory used faith, hope, and love when describing the house of God. The outcome of this mystical ascension of the house of God, to Gregory, is a deeper, but imperfect, knowledge of God. Gregory's mysticism was one that looked to the East but walked West. While Gregory borrowed mystical ideas that echoed the writings of the Desert Fathers in his allegory, it was always bound within the ideas of the West.

The specific thesis of this chapter has been partially driven by historiography which has emphasized the Eastern aspects of Gregory’s theology. In 1989, Carole Straw argued that Gregory the Great's theology was nearer to the Eastern monastic tradition than of the West. ${ }^{63}$ Later, in 2009, Matthew Del Santo compared Gregory the Great's Dialogues with Eustratius of Constantinople's On the State of Souls After Death. In the study, he found that both writers defended the cult of the saints and concluded that Gregory's defense of the cult and its continued

\footnotetext{
${ }^{61}$ DelCogliano, "Introduction," 35.

${ }^{62}$ Straw, Gregory the Great, 123.

${ }^{63}$ Straw, Gregory the Great, 13.
} 
proliferation in the West was thanks to the influence of Byzantine theology. ${ }^{64}$ Finally, in 2015, George Demacopoulos argued that Gregory's mysticism reflected the theology of the East rather than the West. ${ }^{65}$ However, in all of these arguments, they do not mention Gregory's On the Song of Songs. While the allegorical interpretation of the Song of Songs ought to be a window into the mystical understanding of Gregory the Great, these historians did not reference the source when debating whether Gregory's theology reflected the Eastern or Western theological tradition.

Before delving into the source itself, it would help to understand the historical background of the source. Only Gregory's comments on the first eight verses of the Song of Songs survived from this commentary; thus, putting them into historical context has been difficult. Until about twenty years ago historians had dated this commentary to the late 580 s, when Gregory was a monk in the monastery of Saint Andrew. ${ }^{66}$ With new historical information, this conclusion was discredited. Claudius, a monk who recorded and reworked the orations of Gregory of the Great on the Song of Songs, was not at the monastery of Saint Andrew with Gregory the Great but instead went to Rome for four years during Gregory's papacy ${ }^{67}$ Because of this, historians like Paul Meyvaert and Adalbert de Vogüe moved the date of Gregory's commentary from the late 580 s to the late 590 s. $^{68}$

The transcription by Claudius led to another debate on if Gregory the Great actually wrote the source that survives, was it the transcribed and edited version of Claudius, or was it the unrevised notary's version. ${ }^{69}$ Because of the lack of references to the commentary immediately following the death of Gregory the Great, some historians believed that the surviving version

\footnotetext{
${ }^{64}$ Matthew Del Santo, "Gregory the Great and Eustratius of Constantinople: The Dialogues on the Miracles of the Italian Fathers as an Apology for the Cult of the Saints," Journal of Early Christian Studies 17, no 3 (Fall 2009), 457

${ }^{65}$ Demacopoulos, Gregory the Great, Kindle Location 939-940.

${ }^{66}$ DelCogliano, "Introduction," 34.

${ }^{67}$ DelCogliano, "Introduction," 35, 37.

${ }^{68}$ DelCogliano, "Introduction," 35.

${ }^{69}$ DelCogliano, "Introduction," 39.
} 
was the edited version of Claudius. ${ }^{70}$ On the other hand, Mark DelCogliano argues that the argument that this was the original notary's version instead of the edited version of Claudius because of Paul Meyvaert's analysis of the source showed that there were references to spoken discourse and his own refutation of Bernard Capelle's arguments that there were signs of Claudius in the work,. ${ }^{71}$

In Gregory the Great's Commentary on the Song of Songs, he uses faith, hope, and love when describing the house of God. When interpreting the section of the Song of Songs which states that "the king has brought me into his bedchamber," Gregory explained that this bedchamber is part of God's house. ${ }^{72}$ The house has four distinct sections, three which correspond to 1 Corinthians 13 and a final room, the bedchamber. Gregory began by saying that the entrance of the house corresponds with faith, as faith is the entrance to Christianity and it is the beginning for those who want to practice the virtues. ${ }^{73}$ He used Psalm 117:19 in order to strengthen his case, explaining that one who enters the "gates of holiness" will "confess to the Lord." ${ }^{, 74}$ Once one passes through the entrance of faith, they have access to the staircase of hope. Gregory likened hope to a staircase because hope allows Christians to abandon worldly desires in order to pursue those that are lofty. ${ }^{75}$ Again mentioning the Psalms to support his analogy, Gregory uses Psalms 83:6 in order to emphasize that someone with hope "arrang[es] staircases in his heart." $" 76$

The entrance of faith and the staircase of hope then lead to the banquet hall of God which is denoted by charity. Gregory compared charity to a banquet hall because charity is vast, "which

\footnotetext{
70 DelCogliano, “Introduction," 39.

${ }^{71}$ DelCogliano, "Introduction," 40-42.

72 Song of Songs 1:3.

73 Gregory, "Commentary on the Song of Songs," 128. "sicut porta reliqua domus aperit, ita fides reliquarum"

${ }^{74}$ Gregory, "Commentary on the Song of Songs," 128. "Omni, qui intra ecclesiam spem habet, iam ad ascensum domus uenit: spes enim eleuat cor."

${ }^{75}$ Gregory, "Commentary on the Song of Songs," 128.

76 Gregory, "Commentary on the Song of Songs," 128.
} 
extends itself even to the love of enemies."77 Further citing the Psalms, Gregory used Psalms 83:6 to argue that the "vast command" of God, or charity, referred to the vast banquet halls of the house of God. ${ }^{78}$ This charity leads some to search after God's secrets, and those who do this enter into the bedchamber of the King. ${ }^{79}$ Gregory stated that this room is the perfection, or completion, of charity which leads to the pondering of the mysteries of God ${ }^{80}$ Unlike the previous rooms, in which he used the Psalms to support his arguments, he took passages from Isaiah and Paul in 2 Corinthians to show that the prophets and apostles had already achieved this state of being. ${ }^{81}$ Similarly, the Church's leaders and "holy teachers" can reach and understand these "lofty secrets," even during this lifetime. ${ }^{82}$ These teachers can then lift up the congregation to the bedchamber of the King through their teaching. ${ }^{83}$

However, these lofty heights of contemplation are not without warning. Gregory made sure to warn those who go after the secrets of God to not exalt themselves. He used the Biblical figure Ezekiel to make this point, stating that God called him the "son of man" so that he might be aware of his humanity. ${ }^{84}$ Gregory paraphrased this verse using his own New Gregory Translation which reads "Be mindful of what you are. And do not exalt yourself on account of those things to which you have not been raised." 85 Through these passages, Gregory displayed his fear that man, in his grasping of the secret things of God would become filled with pride, thus

\footnotetext{
${ }^{77}$ Gregory, "Commentary on the Song of Songs," 128. "lata enim est caritas, quae usque ad inimicorum dilectionem tenditur."

${ }^{78}$ Gregory, "Commentary on the Song of Songs," 128.

${ }^{79}$ Gregory, "Commentary on the Song of Songs," 128-129. "iam occulta iudicia considerat, quasi in cubiculum intrauit."

${ }^{80}$ Gregory, "Commentary on the Song of Songs," 129. "quartus iam perfectio caritatis as cognitionem secretorum dei."

${ }^{81}$ Gregory, "Commentary on the Song of Songs," 129.

${ }^{82}$ Gregory, "Commentary on the Song of Songs," 129.

${ }^{83}$ Gregory, "Commentary on the Song of Songs," 129.

${ }^{84}$ Gregory, "Commentary on the Song of Songs," 129-130. "Vnde et Hezechihel quotiens ad sublimia contemplanda ducitur, 'filius hominis' uocatur."

${ }^{85}$ Gregory, "Commentary on the Song of Songs," 130. "Adtende, quod es: et non extollaris de his, ad quae adtolleris"
} 
making him fall from his place of contemplation and away from God. Thus, Gregory warned that anyone going through this process must understand whose bedchamber he is entering, the king's; thereby, he must approach it with both reverence and humility. ${ }^{86}$

These ideas about the spiritual life, the rise of man to fuller knowledge of God in contemplation, and the warnings about man's nature did not come from a vacuum, but from a specific theological foundation. Though Gregory did not take the allegory of the bedchamber from any specific writer, previous theologians had heavily influenced his theology. These influences included writers form the Eastern tradition including Origen, Cassian, and the Cappodician Fathers, specifically, Gregory Nazianzen.

Origen was a major source of inspiration for Gregory the Great especially in the Commentary of the Song of Songs. This is because Origen was one of only a few theologians that wrote a commentary, along with homilies, on the Song of Songs. ${ }^{87}$ Although condemned fifty years previously at the Second Council of Constantinople, the works of Origen still could be found in the Latin translations by Jerome and Rufinius. ${ }^{88}$ Because of his use of Origen throughout his works, one can assume that Gregory had access to these translations. ${ }^{89}$ Gregory used the structural and exegetical ideas from Origen throughout the commentary. ${ }^{90}$ As addressed by historians like Joan Peterson, much of the latter half of Gregory the Great's introduction is borrowed directly from Origen. ${ }^{91}$ Additionally, Henri de Lubac states that when considering the totality of Gregory the Great's works, he leaned more on Origen than on Augustine. ${ }^{92}$

\footnotetext{
${ }^{86}$ Gregory, "Commentary on the Song of Songs," 129.

${ }^{87}$ DelCogliano, "Introduction," 85.

${ }^{88}$ Henri de Lubac, Medieval Exegesis Vol I: The Four Senses of Scripture, trans. Mark Sebanc (Grand Rapids, MI: Willian B. Eerdmans Publishing Company, 1998): 163

${ }^{89}$ DelCogliano, "Introduction," 85.

${ }^{90}$ DelCogliano, "Introduction," 86.

${ }^{91}$ Joan M. Petersen, "The Influence of Origen Upon Gregory the Great's Exegesis," Studia Patristica 17 (1985): 343-346.

${ }^{92}$ de Lubac, Medieval Exegesis, 154.
} 
While Gregory the Great borrowed many examples from Origen's Commentary and Homilies, he also adopted Origen's style of allegory throughout the work. This loose style that is seen in the allegory of the house was based on Origen's approaches to allegory in Biblical interpretation. ${ }^{93}$ The allegorical idea that the chamber in the Song of Songs referred to gaining access to a chamber of the king, from which one can gain treasures of the hidden knowledge and wisdom of God was not Gregory's own idea but instead a borrowing from Origen. ${ }^{94}$ Upon this framework Gregory built his own allegory, constructing a building of faith, hope, and love around the chamber, and instead of a treasure chamber Gregory interpreted the room as a bedchamber. ${ }^{95}$ Additionally, Gregory borrowed from Origen when he asked, "why does it not say 'into the bedchamber of the Bridegroom' but into the bedchamber of the king." 96 This is reminiscent of a similar statement of Origen, "It seems to me, however, not without significance that instead of saying 'I was brought in by my Spouse,'...she says it is 'the King's chamber..." $" 97$ This will lead to a departure for Gregory which will be mentioned in the next section. Yet, these examples do show the heavy allegorical influence of Origen on Gregory. The works of John Cassian also influenced the theological ideas of Gregory, especially his thoughts on asceticism and contemplation. While Cassian was a monk in France and wrote in Latin, his works carried the ideas of the Desert Fathers, specifically Evagrius, to a Latin, monastic world. There were not many direct references to him in Gregory's On the Song of Songs because Cassian did not write much about the Song of Songs. Nevertheless, some of his ideas can still be found in Gregory's commentary. Throughout the work, Gregory used the

\footnotetext{
${ }^{93}$ Matter, The Voice of My Beloved, 94.

${ }^{94}$ Origen, "The Commentary on the Canticle of Canticles," in Ancient Christian Writers: The Works of the Fathers in Translation, ed. by Johannes Quasten and Joseph C. Plumpe, trans. by R. P. Lawson, (Westminster, MD: The Newman Press, 1957), 84.

${ }^{95}$ Gregory, "Commentary on the Song of Songs," 128-129.

${ }^{96}$ Gregory, "Commentary on the Song of Songs," 129.

${ }^{97}$ Origen, "The Commentary on the Canticle of Canticles," 85.
} 
different layers of interpretation of Cassian. While it is not readily apparent in this section, the rest of the work is filled with three different modes of interpretation which are found in Cassian's work, including the historical, allegorical, and tropological modes. ${ }^{98}$ The historical mode explains the historical background of the passage, the allegorical mode shows divine revelation to the reader, while the tropological mode reveals spiritual knowledge. ${ }^{99}$

In addition to the abstract theological ideas that Gregory borrowed from Cassian, he also borrowed concrete examples of Christian living from Cassian in his On the Song of Songs. One example of this is Cassian's emphasis that temptations could be helpful to Christians because it keeps them from becoming prideful. ${ }^{100}$ Additionally, Cassian held humility as a high standard, drawing from the writings of Evagrius. ${ }^{101}$ In Cassian's Conferences, he stated that without humility a Christian would not be able to perform miracles because the ability to do them would fill their soul with pride. ${ }^{102}$ Gregory echoed Cassian's sentiment on this idea, saying that when a Christian experiences the mysteries of God in the bedchamber, they must be humble or else they might be swallowed up in pride. ${ }^{103}$ Because Gregory viewed the return to the carnal as cyclical, this return should be something against which a Christian should constantly battle, especially when discerning the secrets of God. ${ }^{104}$ Gregory also followed the idea of Cassian that Christians ought to follow the lives and teachings of previous saints because "they provide examples for virtuous living." 105 This idea was also seen in the allegory of the house, for by following and revering the lives of the saints, the invisible Church can enter the bedchamber. ${ }^{106}$

\footnotetext{
${ }^{98}$ Matter, The Voice of My Beloved, 95.

${ }^{99}$ De Lubac, Medieval Exegesis, 135.

${ }^{100}$ Straw, Gregory the Great, 189.

${ }^{101}$ Demacopoulos, Kindle Location 510.

102 John Cassian, The Conferences, trans. Boniface Ramsey (New York: Newman Press, 1997), 542.

${ }^{103}$ Gregory, "Commentary on the Song of Songs," 129.

${ }^{104}$ Straw, Gregory the Great, 189.

${ }^{105}$ Demacopoulos, Gregory the Great, Kindle Location 941.

${ }^{106}$ Gregory, "Commentary on the Song of Songs," 129.
} 
One other idea of Cassian's that showed up prominently in Gregory's On the Song of Songs was the idea of compunction. This idea originated in monastic writings of the Desert Fathers; however, they were brought to the West by Cassian. ${ }^{107}$ To Cassian, compunction was when the mind had been "'stirred up' by God's grace."108 Through praying, singing hymns, meditation on Scripture, and listening to spiritual teaching from an elder, one was able to be caught up in compunction and driven towards meditation of the things of God. ${ }^{109}$

In his works, Gregory elaborated on this idea brought by Cassian and explained its implications for the Church. Gregory believed that compunction was a "spiritual force involving sorrow for sin, religious awe before the divine judge, detachment from the world, intense longing for heaven, contemplative self-awareness, and... the sweet sorrow that accompanies the necessary decent from the... experience of God." ${ }^{110}$ He emphasized that man could only gain spiritual knowledge through the acts of compunction and contemplation. ${ }^{111}$ In his commentary itself, he explained that compunction was brought about by charity which gives those under its influence the desire to contemplate the bridegroom. ${ }^{112}$ While Cassian introduced the West to compunction, it was Gregory who brought it out of the exclusive minds of the monastery and interpreted it into common theology. ${ }^{113}$

The Cappadocian Fathers also informed the thinking of Gregory the Great. Although Gregory the Great did not know Greek, he was able to attain Latin translations of these theologians. ${ }^{114}$ Gregory of Nazianzen was one Cappadocian Father who greatly influenced the work of Gregory the Great. Gregory of Nazianzen's ideas on the clergy's role in the salvation of

\footnotetext{
${ }^{107}$ Columbia Stewart, Cassian the Monk, (Oxford: Oxford University Press, 1998), 125.

108 Stewart, Cassian the Monk, 125.

109 Stewart, Cassian the Monk, 125-126.

${ }^{110}$ McGinn, The Growth of Mysticism, 50.

111 Straw, Gregory the Great, 121.

112 Gregory, "Commentary on the Song of Songs,"123.

113 Stewart, Cassian the Monk, 125.

114 Straw, Gregory the Great, 13.
} 
others in the Church found within his second Oration, influenced how Gregory would see and interpret the clergy's role in Church. ${ }^{115}$ This idea was reminiscent of the ideas of Cassian; however, they were more clergy-specific rather than focused on the monastery. This idea of the clergy as mediators was not lost in Gregory the Great's On the Song of Songs. Not only through the teaching of those deceased saints who have went into the bedchamber could the Church, in its entirety, enter the bedchamber, but living teachers also provided this benefit. ${ }^{116}$ Through the preaching of the clergy, God could be brought down to the hearts of sinful man. ${ }^{117}$ As this passage was specifically talking about the relation between the Church and the Christian and most teachers in the Church would be the clergy, this passage shows the unique positions that the clergy had as mediators between the Church and the mysteries of God.

Nonetheless, these Eastern theologians were not the only people that influenced the writings of Gregory the Great. The writings of Western theologians like Ambrose and Augustine were also central to Gregorian thought. Gregory had revered these bishops, which can be seen when he recommended the bishop of Ravenna to read the works of Augustine and Ambrose before his own homilies on Ezekiel because they were "deep and clear streams" when compared to his "despicable water." 118 The style of Gregory's allegory in this commentary echoes the writings of Ambrose. ${ }^{119}$ This is because, Ambrose's writings did not shy away from allegorizing the sexual ideas found in the Song of Songs into mystical experiences for the Christian ascetic. ${ }^{120}$ Gregory literally quoted ideas from Ambrose in other areas of the commentary. When commenting on Song of Songs 1:1, he echoed Ambrose when he stated that the kisses of the

\footnotetext{
115 Straw, Gregory the Great, 182.

${ }^{116}$ Gregory, "Commentary on the Song of Songs,"129.

117 Straw, Gregory the Great, 203.

118 DelCogliano, "Introduction," 92-93.

${ }^{119}$ Matter, The Voice of My Beloved, 94.

${ }^{120}$ McGinn, The Growth of Mysticism, 60.
} 
beloved were connected, via historical interpretation, to the woman who kissed Jesus' feet and thereby to the Church's desire to see the second coming of Christ. ${ }^{121}$ Additionally, in Song of Songs 1:2b, Gregory's allegorical interpretation of the ointment being poured out directly mirrored an allegory that was written by Ambrose. ${ }^{122}$ Thus, Ambrose, though never writing a true commentary on the Song of Songs, had theological and allegorical ideas that Gregory used in his commentary and in the rest of his corpus as well.

The thinking of the Western theologian, Augustine, also had a profound influence on Gregory's writings. Augustine's ideas on faith, hope, and love in the context of asceticism helped shape Gregory's allegory of the house of the King. Furthermore, Augustine's influence prominently showed up in the warning about pride and man's nature at the end of the section. Augustine's ideas on faith, hope, and love could be most easily seen in his book to Laurentius, The Enchiridion, in which he explained how a Christian might achieve true wisdom. Augustine argued that true wisdom could only come about through right worship and this worship of God was to be done through faith, hope, and love. ${ }^{123}$ Much like the house, these virtues work together and depend on each other, with Christians starting with faith, following with hope, and then perfecting love. ${ }^{124}$

In addition to the ascension of faith, hope, and love, Augustine also influenced Gregory's thoughts on the nature of man. Following after the ideas of Augustine, Gregory the Great does not view human nature positively, but instead saw its natural stubbornness and resistance to the Gospel. ${ }^{125}$ In the Enchiridion, Augustine stated that while saints are redeemed, in this life they

\footnotetext{
${ }^{121}$ DelCogliano, "Introduction," 94-95.

${ }^{122}$ DelCogliano, "Introduction," 96-97.

${ }^{123}$ Augustine, The Enchiridion, trans. J.F. Shaw, ed. Paul A. Böer, Sr. (Veritatis Splendor Publications, 2012) ,22.

${ }^{124}$ Augustine, The Enchiridion, 24, 28-30.

${ }^{125}$ Straw, Gregory the Great, 207-208.
} 
were still prone to falling into sin of which the Christian needed to repent. ${ }^{126}$ Similarly, Gregory warned Christians pursuing the lofty secrets of God not to fall into the sin of pride. Because of the fall, Gregory posited that the devil has control over the body, making man innately sinful. ${ }^{127}$ This could be most obviously seen in Gregory's warning "Be mindful of what you are," showing that human nature is frail and can easily fall to sinful temptations. ${ }^{128}$

Gregory's theme of not trusting the nature of man and the borrowing of Augustinian ideas was furthered in the last section of his commentary on the Song of Songs. In this section, he compared humans to horses that were attached to either the chariots of God or the chariots of Pharaoh, under whom the devil has control. ${ }^{129}$ In the allegory Gregory explained that there are horses whose lives were full of virtues like preaching, wisdom, and chastity and thereby attached to the chariots of God; however, Gregory stated that people who had these traits could be people who might fall away from the faith and actually be part of the chariots of Pharaoh. ${ }^{130}$

This section tells the reader a lot about Gregory the Great's theology. First, it informed the reader that he is still allegorizing the Song of Songs within the framework of Western theology, specifically that of Augustine. The predestination of God is mysterious and yet gives pity to men to whom He wills. ${ }^{131}$ Furthermore, it showed Gregory continuing with his theme of the sinful nature of man. For if the most virtuous person might still be prone to reprobate conduct which leads to a fall from salvation to damnation, Gregory had very little trust in man's will. Therefore, Gregory borrowed theological ideas from Augustine in order to frame his not only his

\footnotetext{
${ }^{126}$ Augustine, The Enchiridion, 101-103.

${ }^{127}$ Straw, Gregory the Great, 124.

${ }^{128}$ Gregory, "Commentary on the Song of Songs," 130.

${ }^{129}$ Gregory, "Commentary on the Song of Songs," 142-143.

${ }^{130}$ Gregory, "Commentary on the Song of Songs," 143.

${ }^{131}$ Gregory, "Commentary on the Song of Songs," 143-144.
} 
discussion of faith, hope, and love, but also to frame his discussions on the will of man and his predestination.

While Gregory did borrow theological ideas, themes, and styles from the aforementioned theologians, he slightly altered them in order to fit his own unique analysis on asceticism and the mystical results of this ascent. ${ }^{132}$ This section will explain how Gregory shifted the ideas posited by these previous authors when he incorporated them in his On the Song of Songs. First, Gregory modified the ideas of Western theologians, like Augustine, to better fit the model of asceticism. This can specifically be seen in how Gregory shifted the use of faith, hope, and love as seen in Augustine towards a more mystical direction. True wisdom for Augustine was seen in fearing God by practicing faith, hope, and love. ${ }^{133}$ Additionally, Augustine called faith, hope, and love three "graces," which emphasize the necessity for God to grant these graces to Christian followers. ${ }^{134}$

However, Gregory slightly altered these two Augustinian ideas. First, Gregory emphasized that faith, hope, and love were virtues, things that ought to be actively pursued in a Christian's life rather than solely graces of God that are later displayed by Christian works. ${ }^{135}$ Finally, Gregory subverted Augustine's idea that true wisdom was ultimately found in the worship and fear of God through faith, hope, and love. ${ }^{136}$ Instead, Gregory added the bedchamber as a fourth and final section where certain men could be able to penetrate the divine and gain secret knowledge of God. ${ }^{137}$ In doing this, Gregory added a mystical element to the

\footnotetext{
${ }^{132}$ Straw, Gregory the Great, 13.

${ }^{133}$ Augustine, The Enchiridion, 21-22.

${ }_{134}$ Augustine, The Enchiridion, 22.

${ }^{135}$ Gregory, "Commentary on the Song of Songs," 128. Augustine, The Enchiridion, 62-63.

${ }^{136}$ Augustine, The Enchiridion, 21-22.

${ }^{137}$ Gregory, "Commentary on the Song of Songs," 129.
} 
Augustinian explanation of 1 Corinthians 13, an element where love spurs people on to ponder God's secrets. ${ }^{138}$

Additionally, Gregory, while viewing human nature negatively, did not believe it was innately sinful. In fact, he stated earlier in his commentary on the Song of Songs that human nature wants to follow God and His will; however, man has a "habit of weakness" that keeps him back and makes man incapable of chasing after God. ${ }^{139}$ Thus, God needs to draw Christians to Himself. ${ }^{140}$ While very slight, it was an important shift from Augustine. Augustine stated that man nature is helpless to will themselves to God in any capacity because of original sin, thereby the reason why Christians ought to pray for God to work in them. ${ }^{141}$

Whereas Augustine had a totally negative view of human nature, Gregory argued that it is a habit of sin that keeps man's nature from going to God. Gregory emphasized the externality of sin, which contends with the good desires of human nature, rather than seeing evil in the human will as did Augustine. ${ }^{142}$ One reason for this difference was because of the influence of Eastern monasticism on Gregory's thought. ${ }^{143}$ Additionally, this conflict between the body and the soul was also seen in the writings of Cassian and Ambrose, which also may have influenced his shift in Gregory's theology of $\sin { }^{144}$ Through this change in language of sin, one can see how Gregory incorporated Eastern monastic thought on sin with that of Augustine.

This addition of Eastern monastic thought to the ideas of Augustine was not the only theological shifting that Gregory did in his commentary. On the contrary, Gregory bound his mystical experiences within the framework of Western theology. This can be seen in the allegory

\footnotetext{
${ }^{138}$ Gregory, "Commentary on the Song of Songs," 128.

139 Gregory, "Commentary on the Song of Songs," 126.

${ }^{140}$ Gregory, "Commentary on the Song of Songs," 127.

${ }^{141}$ Augustine, The Enchiridion, 65-66.

142 Straw, Gregory the Great, 133.

${ }^{143}$ Straw, Gregory the Great, 133.

144 Straw, Gregory the Great, 111 n. 22.
} 
of the house, where Gregory modified the answer to Origen's question asking why was the chamber referred to the King's chamber and not the spouse's chamber that emphasize his western theological background. When Origen asked the question in his commentary, he responded to his own question by saying that the chamber was called the King's chamber because it is full of God's riches. ${ }^{145}$ This answer was an encouragement for ascetic Christians, as it presented a great reward to those who pressed on and persevered in their ascetic virtues in order to enter the King's chamber. ${ }^{146}$

However, Gregory radically changed Origen's conclusion in his commentary. As was previously noted in the summary of the section, Gregory stated that the bedchamber is called the king's bedchamber because it ought to be shown the most reverence by those who are inside it. ${ }^{147}$ Drawing upon ideas of man's fallen nature by Augustine and Cassian's push for humility, Gregory stated that those in this chamber "ought to be mindful of himself and be all the more humbled by his very progress."148 Thus, this room was not called the king's chamber solely to motivate more people outside to strive to come in. Instead, the designation of it being the king's chamber was a warning for reverence and humility.

This final section will explore the result of this blend of Eastern and Western theological thought by examining the mystical experience in On the Song of Songs, comparing them with Gregory's other thoughts on the mystical outcome of asceticism in order to gain a better picture of the bedchamber of the King. This examination will start with the experience of the individual saint in this mystical encounter, then scrutinize his relation to the Church community as a whole, and finally show that although he might be in a temporary mystical encounter, he still has sinful

\footnotetext{
145 Origen, "The Commentary on the Canticle of Canticles," 85.

146 Origen, "The Commentary on the Canticle of Canticles," 85.

147 Gregory, "Commentary on the Song of Songs," 129.

148 Gregory, "Commentary on the Song of Songs," 129.
} 
flaws. This examination will show that Gregory's work displayed a pattern of Eastern ascetic ideals and mystical experiences bound within the restrictions of Western theology.

As the body is the temple of God, when in total subjection to God, God can use the body to do His will. ${ }^{149}$ Being in the power of God, this "holy man," as Carol Straw typifies him using the saints in Gregory's Dialogues as examples, can care for his flock knowing the secrets of God, tricks of Satan, and minds of his followers. ${ }^{150}$ However, sometimes the miracles that the saint can perform might seem mundane, like fasting and chastity, but they have profound spiritual significance. ${ }^{151}$ Gregory even thought that while miracles do continue they were not as visible as in the early church, and the miracles that were done ought to be in service of bringing Christians closer to God. ${ }^{152}$

Because of this, even "holy men" needed the Church in order to grow in holiness. This is hinted at the beginning of Gregory's allegory when he said that the Church of God is equated to a house. ${ }^{153}$ This is because, to Gregory, the road to the bedchamber was not something that could be accomplished alone, but only with the company of believers. Through the love between a teacher and his disciples, both groups benefitted: one for salvation and the other for stabilization. ${ }^{154}$ Thus, the teachings of the saint could point their disciples' hearts to God through the words they preached and their living examples that they could present to their disciples. ${ }^{155}$

On the other hand, the teacher's disciples could point out lingering sins in a saint's life, driving him to repentance and further holiness. ${ }^{156}$ This is because, to Gregory, the best way to be filled with God was not in contemplation alone, but in the active use of it in other people's

\footnotetext{
149 Straw, Gregory the Great, 96.

${ }^{150}$ Straw, Gregory the Great, 99.

${ }^{151}$ Demacopoulos, Gregory the Great, Kindle Locations 895-896.

152 Demacopoulos, Gregory the Great, Kindle Locations 914-915.

153 Gregory, "Commentary on the Song of Songs," 128.

${ }^{154}$ Straw, Gregory the Great, 201.

155 Straw, Gregory the Great, 71.

156 Straw, Gregory the Great, 103.
} 
lives. ${ }^{157}$ Gregory did not give the highest spiritual rank to those who were contemplative alone, but instead those who lived the "mixed life." ${ }^{158}$ This "mixed life" meant a Christian life that was not solely attached to the contemplative life, but also to serving and teaching others, specifically that of the clergy. ${ }^{159}$ In addition, Gregory's Dialogues show that it was during the church's rituals that miraculous encounters with the divine could occur. ${ }^{160}$ Through these examples it was clear that this mystical experience did not occur alone but through the community provided by the Church.

However, even with the power that God gave select men during life on earth, there were limits to this power. For example, in this life, man could not fully gain a spiritual vision of God. ${ }^{161}$ Additionally, the spiritual experiences that these "holy men" had were usually temporally limited, sometimes to less than an hour's time. ${ }^{162}$ After these mystical moments, the saint fell back down to the earthly life, which at time led to compunction to contemplate the divine more. ${ }^{163}$ At other times, God did not always give the saint what they desired, showing that the saint's hearts are never fully attuned to the will of God. ${ }^{164}$ For example, God did not give Benedict the request for which he prayed; instead, He positively answered the prayers of his sister, Scholastica who prayed against Benedict's request. ${ }^{165}$

Furthermore, even these "holy men" have sinful flaws for which they need to atone. These could include giving into the seemly harmless suggestion of a demon or just acting silly

\footnotetext{
${ }^{157}$ McGinn, The Growth of Mysticism, 77.

${ }^{158}$ McGinn, The Growth of Mysticism, 78.

${ }^{159}$ McGinn, The Growth of Mysticism, 77.

${ }^{160}$ Demacopoulos, Gregory the Great, Kindle Location 992.

${ }^{161}$ McGinn, The Growth of Mysticism, 77.

${ }^{162}$ McGinn, The Growth of Mysticism, 77.

${ }^{163}$ McGinn, The Growth of Mysticism, 64.

164 Straw, Gregory the Great, 104.

165 Straw, Gregory the Great, 104.
} 
and childish. ${ }^{166}$ Nevertheless, it was sometimes through these weaknesses that saints could display their true virtue. ${ }^{167}$ Through Thomas' faithlessness in the resurrection of Christ, man learned more about "spiritual reformation" than by focusing on the near-perfect lives of other saints. ${ }^{168}$ Much like Carole Straw concludes her book on Gregory the Great, "the soul's perfection lies in recognizing imperfection." ${ }^{169}$ By recognizing one's imperfection, saints could see their need for God; therefore, God could use them and receive all the glory, while others could learn spiritual truths from the lives of the saints both through their supernatural strength and natural weakness.

Through the allegory of the house, Gregory the Great displayed how a Christian advances from faith to hope to love in order to end up in the bedchamber of the king. Although influenced by many people including Origen, Cassian, the Cappadocian Fathers, and Augustine, Gregory altered their ideas in order to better explain his own position on Christian mystical experiences. Gregory admitted that ascetic virtue could result in one learning God's hidden knowledge in the bedchamber. This meant that ascetics not only could build up treasure in heaven but also have a chance of experiencing the divine on earth. As can be seen above, the final result of this mystical experience was a better knowledge of the secrets of God and miracles that occurred primarily to benefit others in the Church.

However, Gregory limited this mystical experience. Much like the warning implied, he saw that humanity had weaknesses, including pride, which could make them stumble into sin. Additionally, this knowledge was imperfect because, in this life, man could not fully ponder the vast knowledge of God. Ultimately, Gregory was looking East but walking West. For Gregory

\footnotetext{
166 Straw, Gregory the Great, 103.

167 Demacopoulos, Gregory the Great, Kindle Location 954.

168 Demacopoulos, Gregory the Great, Kindle Location 959.

169 Straw, Gregory the Great, 256.
} 
often looked to the East to instruct him on how to overcome Augustine's unsolvable problem of sin thereby allowing man experience the divine in this life. Nevertheless, his theological allegories did not stray too far from Augustinian ideas about man's sinfulness and God's role in determining the outcome of man's life. 


\section{CHAPTER II: MAXIMUS THE CONFESSOR: TO DEIFICATION WITH LOVE}

Much like Gregory the Great, Maximus the Confessor expounded upon the idea that faith, hope, and love were parts of Christian growth. However, the ultimate result of love was not merely secret knowledge of the divine, but instead deification itself through the grace of God. In this section, I will argue that because of Maximus' theological foundation was built upon not only the writings of the Desert and Cappodocian Fathers but, more importantly, the ideas of both Neo-Platonism and Pseudo-Dionysus, Maximus believed that faith, hope, and love led Christians towards the ultimate goal of deification, a mystical experience that allows God to physically work in humanity through the deified person.

Maximus the Confessor's theological ideas did not come from the once-exalted city of Rome, but instead from across the Mediterannean Sea, most likely in North Africa. ${ }^{170}$ There, Maximus the Confessor wrote a letter to John the Cubicularius, who worked as a courtier in Constantinople, and others living in the imperial capital, as denoted by Maximus' use of the second person plural pronoun in the work. ${ }^{171}$ Written around $633 \mathrm{CE}$, Maximus would use the letter to expound on the centrality of love to Christianity, how love is corrupted by Satan into self-love, and the role that love ought to play in the life of Christians.

Authors in the Eastern Roman Empire during and after the time of Maximus the Confessor wrote multiple histories about the theologian. The three most well known versions, written in Greek, generally agreed that Maximus the Confessor came from a noble family in Constantinople and became an imperial secretary before renouncing the imperial life to live as a

\footnotetext{
${ }^{170}$ Marek Jankowiak and Phil Booth, "A New Date-List of the Works of Maximus the Confessor," in The Oxford Handbook of Maximus the Confessor ed. Pauline Allen and Bronwen Neil, (Oxford: Oxford University Press, 2015), 37.

${ }^{171}$ Andrew Louth "Introdction to 'Letter 2: On Love,"” in Maximus the Confessor (London: Routledge, 1996$), 84$.
} 
monk. ${ }^{172}$ Unfortunately, recent research into these accounts concluded that the earliest of these texts dated to the end of the tenth century and the chronology accounted in the sources was not accurate. ${ }^{173}$ Nevertheless, Polycarp Sherwood used the Greek sources to create a chronology of Maximus the Confessor in 1952. ${ }^{174}$ This chronology was a standard reference for those studying and examining the life of Maximus up until the 2000s.

However, this history of Maximus was later challenged by the discovery of a Syriac Life that survived from a seventh-century manuscript. ${ }^{175}$ Written by a clergy member of Patriarch Sophronius' church in Jerusalem, this source was hostile to Maximus the Confessor and gave a completely different narrative of Maximus' life. ${ }^{176}$ Notable events included a Palestinian birth to a Samaritan and Persian slave girl, becoming a Palestinian monk, and later consulting with Origenists, pagans, and Nestorians. ${ }^{177}$ Because of the disparaging nature of this account and major timeline gaps found in the Syriac version, scholars have been divided on how useful this source is to determining the life of Maximus the Confessor. ${ }^{178}$

Yet, as Marek Jankowiak and Phil Booth explain, with more scholarly research informing the way this period is understood by historians, the Syriac Life proves to be an invaluable source, despite the source's maleficent intentions. ${ }^{179}$ His Palestinian origins also better explain both Maximus' Neo-Platonic philosophical background and his critiques of Origen, as summarized by Pauline Allen's article examining the life of Maximus the Confessor. ${ }^{180}$ This revised chronology

\footnotetext{
172 Allen, "Life and Times of Maximus the Confessor," 10, 13.

173 Allen, "Life and Times of Maximus the Confessor," 10-11.

${ }^{174}$ Marek Jankowiak and Phil Booth, “A New Date-List of the Works of Maximus the Confessor,” 19.

175 Allen, "Life and Times of Maximus the Confessor," 13.

176 Allen, "Life and Times of Maximus the Confessor," 13.

177 Allen, "Life and Times of Maximus the Confessor," 13.

${ }^{178}$ Allen, "Life and Times of Maximus the Confessor," 13.

${ }^{179}$ Marek Jankowiak and Phil Booth, "A New Date-List of the Works of Maximus the Confessor," 19.

${ }^{180}$ Allen, "Life and Times of Maximus the Confessor," 13.
} 
set forth by Marek Jankowiak and Phil Booth based on the Syriac Life will be the basis of the historical context for this chapter.

Ten years after his birth in Palestine in $579 \mathrm{CE}$, Maximus became a monk in the monastery of Chariton located in the Judean Desert. ${ }^{181}$ In 617, he met his disciple Anastasius, who previously had imperial connections as a notarios. ${ }^{182}$ In the early 630 s, Maximus fled Palestine because of the Persian invasion of the southern regions of the Eastern Roman Empire, including Palestine and Egypt, and found refuge in North Africa. ${ }^{183}$ It was in North Africa, or afterwards when he returned to Palestine, that Maximus wrote the letter to John the Cubicularius. ${ }^{184}$ Unfortunately, the letter does not give much information to precisely when and where the letter was written. Thus, when creating a new chronology of Maximus the Confessor's corpus, Jankowiak and Booth use the context of the letters, including the themes of presence, absence, and the lack of arguments against monothelitism, to place the writing of the letter to around $630 \mathrm{CE} .{ }^{185}$

During this tumultuous time, Maximus writes to John the Cubicularius. He opens the letter by encouraging John to hold onto to "holy love towards God and your neighbor." 186 This is because Maximus found John's love for humanity and suffering as a sign of God's work. ${ }^{187}$ Maximus then explained love in terms of 1 Corinthians 13, stating that love completes not only faith and hope but also all of the fruits of the Holy Spirit. ${ }^{188}$ Returning to faith and hope in greater detail, Maximus revealed that faith is the foundation of hope and love in the Christian

\footnotetext{
181 Jankowiak and Phil Booth, "A New Date-List of the Works of Maximus the Confessor," 20.

182 Jankowiak and Phil Booth, "A New Date-List of the Works of Maximus the Confessor," 20.

183 Jankowiak and Phil Booth, "A New Date-List of the Works of Maximus the Confessor," 20.

${ }^{184}$ Jankowiak and Phil Booth, "A New Date-List of the Works of Maximus the Confessor," 37.

${ }^{185}$ Jankowiak and Phil Booth, "A New Date-List of the Works of Maximus the Confessor," 37.

${ }^{186}$ Maximus, "Letter 2: On Love," 85.

187 Maximus, "Letter 2: On Love," 85.

${ }^{188}$ Maximus, "Letter 2: On Love," 86.
} 
life, for it forms the bedrock of truth. ${ }^{189}$ Additionally, hope strengthens both faith and love, teaching the Christian to run the race to completion. ${ }^{190}$ However, to Maximus, love is the completion of these desires, for it leads the soul to rest by "giv[ing] faith the reality of what it believes and hope the presence of what it hopes for." ${ }^{191}$ Afterwards, Maximus did not explain the result of this Christian love; instead, he explained how the devil corrupted godly love into a love for self. ${ }^{192}$ Through yearning and struggle, Christian reason ought to seek after a love for God alone which, ultimately, unifies them with each other and with God, purifing them of the passions which war against their spirit. ${ }^{193}$ This then allows the Christian, like Abraham, to be "made God, and God is called and appears human." ${ }^{194}$ By that phrase, Maximus meant that God appears human through the purified Christian.

Consequently, this ascetic struggle to attain a perfect love for God leads to the ultimate result of a Christian's growth through faith, hope, and love: deification. Maximus wrote that a perfected love "will embrace God and manifest the one who loves God to be God himself." $195 \mathrm{He}$ also explained the reason that humanity is able to become deified. He stated that through the hypostatic union, God bound himself to human nature. ${ }^{196}$ Furthermore, because of Jesus' death and resurrection, He was able to restore human beings and God to their natural state of union with one another. ${ }^{197}$ Near the end of the letter, Maximus repeated the idea, stating that the hypostatic union, God "establishes the all-glorious way of love, which is truly divine and

\footnotetext{
${ }^{189}$ Maximus, “Letter 2: On Love," 86.

${ }^{190}$ Maximus, "Letter 2: On Love," 86.

${ }^{191}$ Maximus, "Letter 2: On Love," 86

192 Maximus, "Letter 2: On Love," 87.

193 Maximus, "Letter 2: On Love," 87-89.

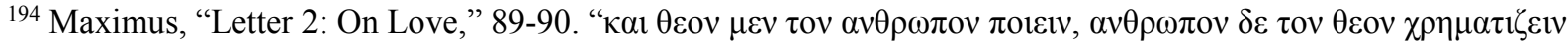

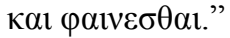

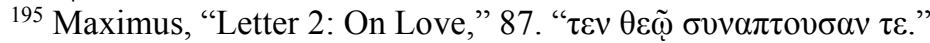

196 Maximus, "Letter 2: On Love," 87.

${ }^{197}$ Maximus, "Letter 2: On Love,” 87-88.
} 
deifiying and leads to God." ${ }^{198}$ Thus, because God took on the flesh of humankind, man is able to become like God through deification via the grace of God and virtuous living through asceticism. This is a grace of God for only His love is able to "raise up human beings to deification." 199

This idea of asceticism leading to deification is mentioned throughout the letter. Specifically, it is through the "ascetic struggle" that God takes the form of humankind in a Christian's life. ${ }^{200}$ As mentioned above, Maximus explained that just as Abraham was able to receive God through his love of humankind, so can Christians be united with God as the fulfillment of love. ${ }^{201}$ At the very end of the letter, Maximus stated that through virtues by grace one becomes deified, sublimating human flesh and bringing on divine properties. ${ }^{202}$

Though this path is a struggle for the ascetic Christian, requiring virtue and grace, Maximus placed few warnings or limitations on deification. He gave no warning of pride that would occur after one achieved this goal, instead there is only a vague limitation placed upon deification which can be found in a couple places in the letter. Maximus stated in these phrases that this assumption to God through virtue happens "so far as is possible for humans." ${ }^{203}$ Thus, to Maximus the Confessor, the development of faith, hope, and love through asceticism, together with the grace of God, leads to deification, a union of the ascending man and the descending of God leading to man becoming God himself.

However, Maximus' understanding of deification came from a particular blend of theological and philosophical ideas. Philosophically, Neo-Platonic thought, especially that of

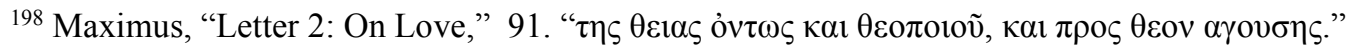

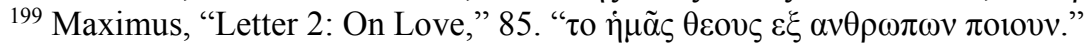

${ }^{200}$ Maximus, "Letter 2: On Love," 90.

${ }^{201}$ Maximus, "Letter 2: On Love," 90.

202 Maximus, "Letter 2: On Love," 93.

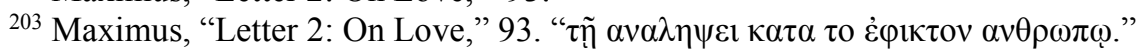


Proclus, heavily influenced the theological interpretations of Maximus the Confessor.

Additionally, Maximus borrowed a majority of his theology from three central theological roots: the works of Pseudo-Dionysius, the Desert Fathers, and the Cappadiocian Fathers. ${ }^{204}$ Ideas drawn from these foundations helped to shape Maximus' own construction of the theological doctrine of deification.

Most importantly, Maximus' thoughts on deification had been heavily influenced by the philosophical theories of Neoplatonism. Certain theologians which Maximus referenced, like Pseudo-Dionysus, merged the ideas of Plotinus and Proclus with previous Christian thought. ${ }^{205}$ By combining both Neo-platonic philosophy and patristic Christian thought, Maximus created "new synthesis of patristic teaching." ${ }^{" 206}$ Consequently, Neo-Platonic influence was so prominent in Maximus' works that some space ought to be devoted to examining the Neoplatonic influences of Plotinus and Proclus. The most obvious Platonic reference in the letter actually can be found in his vague limitation of deification. Specifically, Maximus borrowed the phrase "so far as is possible for humans" from Plato himself in the Phaedrus, who argued that through the dialectic man can come to understand the true Forms of the logos "to the extent that is humanly possible." ${ }^{207}$ Though this phrasing was not solely used by Plato but also by Jewish thinkers like Philo and Christian theologians like Clement of Alexandria and Psuedo-Dionysus, Maximus' use of the phrase shows the deep influence that Platonic thought had on Christian theology. ${ }^{208}$ This was not the only influence of Platonic thought on the Maximus the Confessor's theology. Additionally, Maximus used negative theology in his work, which ultimately stemmed

\footnotetext{
${ }^{204}$ Louth, "Introduction," 26-32.

${ }^{205}$ Russell, The Doctrine of Deification, 258.

${ }^{206}$ Russell, The Doctrine of Deification, 263.

${ }^{207}$ Daniel S. Werner, Myth and Philosophy in Plato's Phaedrus, (Cambridge: Cambridge University Press, 2012), $153,172$.

${ }^{208}$ Russell, The Doctrine of Deification, 1, 12, 85.
} 
from Plotinus' idea of "the ineffability of the One." ${ }^{209}$ Negative theology is when one tries to understand the identity of God by identifying what He is not. ${ }^{210}$ This can be seen at the end of the letter, when Maximus claimed that God is "unfailing and unalterable." 111 In this, Maximus did not characterize God by what He is but instead by what He is not. Though this form was also popularized by the Cappadocian Fathers and Pseudo-Dionysus, the influence of Neo-Platonic thought on Maximus' writings should not be overlooked.

Additionally, the influence of the Neo-Platonic thinker Proclus was evident in the thoughts and ideas of Maximus the Confessor. Maximus' vision of the cosmos, and thereby his philosophy about deification, was shaped by Proclus' Neoplatonic ideas of human participation with the divine. ${ }^{212}$ One example of this is when Maximus borrowed the Proclean idea of participation in the divine through "kinship and likeness." 213 This idea posited that since people had some connection to the divine, at least through the act of creation, man could participate in the divine through virtue and asceticism which could be perfected by love. ${ }^{214}$

These Proclean ideas can be seen in Maximus' letter in a few places. First, the kinship to the divine was asserted when Maximus stated that love solely proves that humanity was created in the image of God. ${ }^{215}$ Furthermore, he emphasized participation with the divine when stating that God could inhabit a Christian, who through virtue-gaining asceticism was now unified to the logos of nature. ${ }^{216}$ Lastly, Maximus continued to echo the ideas of Proclus when he explained that the highest place to which the soul could ascend can only be gained through the love of God

\footnotetext{
${ }^{209}$ Pauliina Remes, Neoplatonism, (Berkley, CA: University of California Press, 2008), 204.

${ }^{210}$ Remes, Neoplatonism, 204.

${ }^{211}$ Maximus, "Letter 2: On Love," 92.

${ }^{212}$ Cooper, The Body in St. Maximus the Confessor, 115.

${ }^{213}$ Russell, The Doctrine of Deification, 256.

${ }^{214}$ Russell, The Doctrine of Deification, 257.

${ }^{215}$ Maximus, "Letter 2: On Love," 86.

${ }^{216}$ Maximus, "Letter 2: On Love," 87, 90.
} 
and the love of man. ${ }^{217}$ Thus, very specific ideas about God, deification, and its limits as described in this letter came from Neo-Platonic thought. Consequently, its influence can be seen throughout the writings of Maximus the Confessor.

While parts of Maximus' view of cosmology and deification came from the ideas of NeoPlatonism, the Eastern theological tradition shaped his Christian understanding of doctrine. One theologian of this tradition who was heavily referenced by Maximus was Pseudo-Dionysus the Areopagite. Dionysius' blend of Neoplatonic philosophy, patristic theology, Christian liturgy, and cosmological understanding profoundly influenced the way that Maximus the Confessor saw the role of Christianity in the world. ${ }^{218}$ In the Mystagogy, Maximus even acknowledged him by name, calling him "the most holy and divine interpreter." ${ }^{219}$ Pseudo-Dionysus helped develop Maximus' ideas of the role of the church and liturgy in Christian deification. He argued that by participating in the liturgy and in the community of believers, Christians were drawn closer to God and disclosed it to those involved. ${ }^{220}$ Maximus' letter also emphasized participation in the community of believers, stating that those who practice virtue will draw themselves to their neighbors, ultimately being bound together and raised to God. ${ }^{221}$

However, Maximus not only gained a better understanding of the centrality of community from Pseudo-Dionysus but he also gained a fuller vision of the hierarchical cosmos and its relation to deification. ${ }^{222}$ To Pseudo-Dionysus, the hierarchy, or ordering of the universe, had heavy implications for deification. Pseudo-Dionysus stated that God's planned hierarchy

\footnotetext{
${ }^{217}$ Maximus, "Letter 2: On Love," 90.

${ }^{218}$ Louth, "Introduction," 28-30.

219 Thomas Cattoi, "Liturgy as Cosmic Transformations," in The Oxford Handbook of Maximus the Confessor ed. Pauline Allen and Bronwen Neil, (Oxford: Oxford University Press, 2015), 418.

${ }^{220}$ Louth, "Introduction," 30.

${ }^{221}$ Maximus, "Letter 2: On Love," 88-89.

222 Louth, "Introduction," 31.
} 
"enables[s] beings to be as like as possible to God and to be at one with him." ${ }^{223}$ Additionally, regarding the Christian union to God, Maximus borrowed two terms from Pseudo-Dionysus: "union beyond intellect" and "union 'with the One.",224 These phrases, used in Maximus' Mystagogy, explained what the union with God would be once all Christians were deified in the coming age. ${ }^{225}$ Thus, Maximus was able to use Pseudo-Dionysus' vision of the cosmos, both in the church and throughout the universe, in order to gain a better understanding of its role in the ascent of a Christian towards God.

Pseudo-Dionysus was not the only theological source of Maximus' thought. In addition, many of Maximus' ideas were heavily influenced by the writings of the Desert Fathers. One that was foundational to his theology was Origen. Although Maximus critiqued the heretical ideas of Origen, he tried to assimilate Origenist ideas about biblical interpretation into his theological discussions. ${ }^{226}$ Origin's terms and concepts appeared throughout the corpus of Maximus and thereby showed a great depth of understanding of Origen's works. ${ }^{227}$

One example of this understanding was when Maximus used Origen's theological concept of transposition in his in letter On Love. Transposition is an allegorical style of interpretation in which a Biblical figure is placed as a forerunner to the audience of the work. ${ }^{228}$ This can be seen in the letter when Maximus explained that Abraham was the forerunner of John the Cubicularius and the other readers as both lived with a love for humanity. ${ }^{229}$ Although Maximus did borrow many ideas from Origen's work, he also modified it in order to remain in

\footnotetext{
${ }^{223}$ Louth, "Introduction," 31.

${ }^{224}$ Ysabel de Andia, "Pseudo-Dionysius the Areopagite and Maximus the Confessor," in The Oxford Handbook of Maximus the Confessor ed. Pauline Allen and Bronwen Neil, (Oxford: Oxford University Press, 2015 ), 190.

225 de Andia, "Pseudo-Dionysius the Areopagite and Maximus the Confessor," 191.

${ }^{226}$ Blowers, Exegesis and Spiritual Pedagogy in Maximus the Confessor, 4.

${ }^{227}$ Cattoi, "Liturgy as Cosmic Transformations," 418.

${ }_{228}$ Paul M. Blowers, "Exegesis of Scripture," in The Oxford Handbook of Maximus the Confessor ed. Pauline Allen and Bronwen Neil, (Oxford: Oxford University Press, 2015), 254.

${ }^{229}$ Maximus, “Letter 2: On Love," 89-90.
} 
an orthodox framework. For example, Maximus changed Origen's heretical triad of the movement of human souls "abiding-movement-becoming" to the more orthodox "becomingmovement-rest," where rest is found in deification. ${ }^{230}$ While Maximus did write against the teachings of Origen, he drew much inspiration from Origen as well, which greatly influenced the way Maximus examined and interpreted the Bible.

Although Origen greatly influenced the ideas of Maximus, Origen's disciple, Evagrius Ponticus, also had a major role in shaping the theology of Maximus. The role of prayer in asceticism and the conception of passions that are found in Maximus' works can be traced back to Evagrius. ${ }^{231}$ One important theme was Evagrius' emphasis on the importance of the ascetic struggle for Christian growth. ${ }^{232}$ Maximus drew upon this in his letter when he explained that ascetic struggle was necessary for the deification of the Christian and that ascetics must constantly resist sin and endure "many forms of death" to be united to God. ${ }^{233}$

Additionally, Maximus borrowed his understanding of human passions from the writings of Evagrius. The reason for entering ascetic struggle, to Evagrius, was to war against the "passions," like fornication, grief, and pride, ultimately reaching a state of dispassion. ${ }^{234}$ This same struggle against the passions was adopted by Maximus. For example, in his letter, Maximus stated that out of self-love, the corrupted form of actual love, comes all the passions and only by being unified with the logos can one be free from these passions. ${ }^{235}$

\footnotetext{
${ }^{230}$ Torstein T. Tollefsen, "Christocentric Cosmology," in The Oxford Handbook of Maximus the Confessor ed. Pauline Allen and Bronwen Neil, (Oxford: Oxford University Press, 2015), 314.

${ }^{231}$ Marcus Plested, "The Ascetic Tradition," in The Oxford Handbook of Maximus the Confessor ed. Pauline Allen and Bronwen Neil, (Oxford: Oxford University Press, 2015), 166.

${ }^{232}$ Louth, "Introduction," 36-37.

${ }^{233}$ Maximus, "Letter 2: On Love," 90-91.

${ }^{234}$ Louth, "Introduction," 36.

${ }^{235}$ Maximus, "Letter 2: On Love," 88-89.
} 
However, as Marcus Plested and Andrew Louth both point out, Maximus altered the ideas of Evagrius. ${ }^{236}$ For example, the natural passions, which were originally thought of as negative by Evagrius, have important roles to play in the growth and deification of the Christian in the cosmology of Maximus the Confessor. ${ }^{237}$ Additionally, while Maximus borrowed the ascetic struggle from the ideas of Evagrius and Origen, as noted previously, he diverged from them in asceticism's ultimate outcome. Whereas Evagrius' earthly end for humanity was "intellectual worship" the end for Maximus was humanity deified. ${ }^{238}$ Thus, much like the ideas of Origen, Maximus not only heavily borrowed from but also altered the teachings of Evagrius.

One final Desert Father who was central to the thinking of Maximus the Confessor, especially in relation to deification, was Marcarius. In Marcarius' fourth homily, he was amazed how God unites himself with worthy souls, "enveloping" the bodies of saints and allowing them to participate in the divine. ${ }^{239}$ In the same homily, Marcarius explained how God does that by being a "hypostasis in the hypostasis" so that the worthy man would be able to fully live and partake in the divinity and glory of God through him. ${ }^{240}$ This idea of union with God via the hypostatic union of Christ was central to Maximus' teachings on deification. Maximus stated in his letter that through the hypostatic union the nature of man and the Christian were unified and the path towards deification is open to them. ${ }^{241}$

Furthermore, Marcarius emphasized the importance of experience and prayer in his writings, and these ideas influenced the way that the Christian perceived the ascetic life. ${ }^{242}$ Thus, the ascetic experience was not just a display of Christian piety but it also could culminate into a

\footnotetext{
${ }^{236}$ Louth, "Introduction," 37-38, Plested, 166-167.

${ }^{237}$ Plested, "The Ascetic Tradition," 166.

${ }^{238}$ Cattoi, "Liturgy as Cosmic Transformations,"429-430.

239 Plested, "The Ascetic Tradition," 169.

${ }^{240}$ Plested, "The Ascetic Tradition," 169.

${ }^{241}$ Maximus “Letter 2: On Love,” 87-88, 91.

${ }^{242}$ Louth, "Introduction," 25.
} 
personal experience with the divine. Maximus, in turn, spoke of experience often in his works, including the Christian experience of "divine power" and of "rebirth in the Spirit." of the letter, Maximus encouraged John by pointing out divine experiences that the Scripture promised to those who endure including a section from Baruch 3:4-5 that stated that "God will show your splendor everywhere under heaven..." before stating that God had already united Himself with John through deification. ${ }^{244}$ Thus, the idea of God taking on and descending on humanity through human experience was an idea that would greatly influence Maximus' doctrine on humanity's deification.

In addition to the Desert Fathers, Maximus was deeply influenced by the Cappodician Fathers. Because of the Origenist controversy, the Cappadocian Fathers were central reading material for theologians during the time of Maximus the Confessor. ${ }^{245}$ Although these fathers were central to Maximus the Confessor's theology, the two Gregorys, Gregory of Nazianzus and Gregory of Nyssa, were most influential.

Maximus' engagement with the works of Gregory of Nazianzius can most easily be found in his Difficulties, where he explained and even reinterpreted difficult passages from Gregory’s works. ${ }^{246}$ In spite of this, there were some ideas that Maximus fully took from Gregory of Nazianius. For example, Maximus borrowed Gregory of Nazianzius’ words $\theta \varepsilon o ́ \omega$ and $\theta \varepsilon \dot{\varepsilon} \omega \sigma \iota \varsigma$, using them to describe the deification of man. ${ }^{247}$ However, most often he explained difficult passages in Gregory of Nazianius' works. In his Ambigua ad Iohannem 7, Maximus reinterprets Gregory's phrase "a portion of God," explaining that it meant to "participate in God

\footnotetext{
${ }^{243}$ Plested, "The Ascetic Tradition," 171.

${ }^{244}$ Maximus, "Letter 2: On Love," 93.

245 Blowers, Exegesis and Spiritual Pedagogy, 5.

${ }^{246}$ Louth, "Introduction," 27.

${ }^{247}$ Russell, The Doctrine of Deification, 263-264.
} 
through the practice of virtue. ${ }^{248}$ Furthermore, in Difficulty 10, Maximus altered Gregory's explanation of the ascension of man to God, changing it from an ascension using reason and contemplation alone to an ascension that hinged upon the ascetic struggle of the Christian. ${ }^{249}$

While much of Gregory of Nazianzius' influence was seen through Maximus' engagement with his difficult topics, the influence of Gregory of Nyssa could be seen by Maximus' use and evolution of specific themes brought up by the younger Gregory. For example, Maximus borrowed Gregory of Nyssa's idea of "ever-moving rest" in order to describe the Christian's ascetic struggle towards deification. ${ }^{250}$ Additionally, Maximus borrowed from Gregory of Nyssa's idea that the deified body of Christ is unified with that of the believer in the Eucharist. ${ }^{251}$ Just like Gregory of Nazianzius, there were also ideas from Gregory of Nyssa upon which Maximus the Confessor modified. One example of this is seen in Maximus' Ad Thalassium wherein he added the importance of "monastic ascesis" to Gregory of Nyssa's teaching on transformation of the soul's faculties. ${ }^{252}$

Maximus combined sources which, as seen above, were taken from both Christian and pagan origins and blended them together to created a unique understanding of deification. While this letter only gives a small glimpse of Maximus' view of deification, this next section will put the letter in context within Maximus' other teachings on deification in order to demonstrate how Maximus synthesized these ideas into his doctrine of deification. When examining Maximus' statements on deification, there emerge three clarifying elements of deification: the way

\footnotetext{
${ }^{248}$ Cooper, The Body in St. Maximus the Confessor, 91.

${ }^{249}$ Louth, "Introduction," 44.

${ }^{250}$ Andreas Andreopoulos, "Eschatology in Maximus the Confessor," in The Oxford Handbook of Maximus the Confessor ed. Pauline Allen and Bronwen Neil, (Oxford: Oxford University Press, 2015), 324, 328.

${ }^{251}$ Lars Thunberg, Microcosm and Mediator: The Theological Anthropology of Maximus the Confessor, (Chicago: Open Court Publishing Company, 1995), 428.

${ }^{252}$ Blowers, Exegesis and Spiritual Pedagogy, 58.
} 
humanity may be deified, the place in which man might be deified, and finally the result of man's deification.

First, one must answer the question how man becomes deified. As stated in his letter to John, Maximus argued that it is through Christ's incarnation that man could be deified. When doing this, he expanded on the ideas set by Pseudo-Dionysus and Marcarius. In his Ambigua 10, Maximus uses a tantum-quantum formula to create a logical argument to justify the deification of humanity. ${ }^{253}$ Maximus' use of this formula echoes the argument of Marcarius about the hypostatic union, saying that just as Christ took on human flesh and became man, man can take on deification, with "mutual penetration and communication.." ${ }^{254}$ Furthermore, Maximus wrote "as much as God is humanized to man through love for mankind, so much is man able to be deified to God through love." 255

However, although Christ's incarnation allows man's ability to become deified, Maximus underlined that this was only due to the grace of God. Thus, as can be seen in Maximus' first Opusculum, theosis only comes about by the grace of God actively working in a Christian's life, which allows them to put aside their earthly life for that of the divine. ${ }^{256}$ Maximus stated in his Capita de Caritate that Christians could become "what God is by essence" through participation and partaking of the divine. ${ }^{257}$ This putting aside the earthly life and participation of the divine means that the process of deification was not a passive one, but instead one where the Christian must actively deny himself through asceticism. As stated by George Berthold and expanded by Adam G. Cooper, the body ought to suffer in order to gain virtue as it is deified, much as Christ's

\footnotetext{
253 Thunberg, Microcosm and Mediator, 431.

254 Thunberg, Microcosm and Mediator, 431.

${ }^{255}$ Maximus the Confessor, "Difficulty 10," in Maximus the Confessor, trans. and ed. Andrew Louth, (New York: Routledge, 2006), 101.

${ }^{256}$ Russell, The Doctrine of Deification, 277.

${ }^{257}$ Russell, The Doctrine of Deification, 266.
} 
life and death was full of suffering. ${ }^{258}$ Since, asceticism allowed Christians to suffer for virtue, mortifying their flesh so they might reflect Christ in their works, humanity could be "penetrated by and transformed by the divine." 259

Though deification comes about through a combination of God's grace and ascetic suffering, Maximus denoted a specific location out of which deification occurs: the Church. The church was the place where man could participate in a micro-universe that was directly moved by God through the body of Christ. ${ }^{260}$ In the Church alone one could hear the preaching of the Word and witness others who had gained virtue through suffering. ${ }^{261}$ Additionally, Christians could come together with other Christians, showing love for one another, and this, as stated by Maximus in his letter, draws Christians closer to deification. ${ }^{262}$

Furthermore, through the recitation of the Lord's Prayer and the Eucharist offered by the Church, man can "be deemed worthy to abandon his human status and become a god."."63 Through the symbolism found throughout the church, from the liturgy to the mystery of the Eucharist, Christians were able to participate in the divine, even going as far to say in the Mystagogia that they could pass through this world "into "the bridal chamber of Christ."264 Through the use of Biblical and creedal recitations, singing of hymns, and the aforementioned mysteries of the Eucharist, the Holy Spirit could lift humanity up to deification. ${ }^{265}$ From this brief description, one can see that deification most often occured in the location of the Church. The concepts of coming together with one another, taking the Eucharist, and singing hymns all

\footnotetext{
${ }^{258}$ Adam G. Cooper, The Body in St. Maximus the Confessor: Holy Flesh, Wholly Deified, (Oxford: Oxford University Press, 2005), 241-243.

${ }^{259}$ Russell, The Doctrine of Deification, 264,

${ }^{260}$ Russell, The Doctrine of Deification, 264. Cooper, The Body in St. Maximus the Confessor, 167.

${ }^{261}$ Cooper, The Body in St. Maximus the Confessor, 195.

${ }^{262}$ Russell, The Doctrine of Deification, 273.

${ }^{263}$ Russell, The Doctrine of Deification, 272.

${ }^{264}$ Cooper, The Body in St. Maximus the Confessor, 204.

${ }^{265}$ Russell, The Doctrine of Deification, 272.
} 
point towards not primarily the universal church as a place of deification but instead the physical church, for it was within the church that the true order of the cosmos could be understood and participated.

For Maximus, deification restored humanity back to the position it once held in Genesis 1 as image bearers of God. ${ }^{266}$ Additionally, as Jean-Claude Larchet points out, deification changed the essence, or tropos, of who a person was without violating their logos of being human. ${ }^{267}$ This change in a Christian's "mode of existence" overcame his natural thoughts and even his intellect, driving him to reject the world in order to continue his union with God. ${ }^{268}$ This mode also changed their relationship with nature, for deified Christians transcended natural laws and desires, with their intellect being redirected towards the wisdom of God rather than of mankind or nature. ${ }^{269}$

It is through this reasoning that Maximus stated that only through deification could Paul have ascended into the third heaven. ${ }^{270}$ While deification was fulfilled after death, it could be anticipated in certain degrees while living on earth. ${ }^{271}$ Maximus explained that through the mortification of the body certain saints were able to earn in this life what usually only occured after death. ${ }^{272}$ Thus, God gave certain Christians a taste of the deification that is to come. ${ }^{273}$ However, to Maximus, deification was an endless and infinite process, even after death, for God's essence is infinite, transcending all space and time. ${ }^{274}$

\footnotetext{
${ }^{266}$ Russell, The Doctrine of Deification, 278.

${ }^{267}$ Larchet, "The Mode of Deification," 342-343.

${ }^{268}$ Larchet, "The Mode of Deification," 347.

${ }^{269}$ Larchet, "The Mode of Deification," 347-348.

${ }^{270}$ Russell, The Doctrine of Deification, 280.

${ }^{271}$ Russell, The Doctrine of Deification, 262.

272 Cooper, The Body in St. Maximus the Confessor, 246.

${ }^{273}$ Larchet, The Doctrine of Deification, 348.

${ }^{274}$ Cooper, The Body in St. Maximus the Confessor, 115.
} 
Although most of this examination of deification has been philosophical, Maximus explained that there was a practical outcome of deification: the creation of physical mediators on Earth. While man was originally supposed to be the mediator between God and nature in the beginning, man's sin kept humanity from fulfilling that destiny. However, through Christ, deified man can effectively accomplish his role as mediator between God and man. ${ }^{275}$ Deified man can represent God on earth, offering himself as a meeting-ground where others can meet God and be deified themselves. ${ }^{276}$ Through the coordination of human and divine wills via asceticism, God is revealed as incarnate in the deified man to others seeking God. ${ }^{277}$ Thus, deification is able to make man a true mediator for God, since he has God living in and through him.

This chapter has explored the result of faith, hope, and love for Maximus the Confessor: deification. Blending words, ideas, and theories from a vast combination of patristic and philosophical sources, Maximus created a unique construction of deification. The path to deification was hard, riddled with ascetic suffering. It was also something that could not be done alone, for one needed the grace of God and the Church in order to achieve deification. Nevertheless, the resulting experience of deification, as told by Maximus, was supernatural, allowing God to physically work in humanity through the deified person allowing man to both continue to grow in godliness and assume their God-given role as mediator between God and nature.

This result of faith, hope, and love contrasted drastically from that given by Gregory the Great. In Gregory, man might only get a glimpse of heavenly mysteries, in Maximus they were participating in them. While in Gregory, one approached the king's bedchamber with reverence,

\footnotetext{
${ }^{275}$ Russell, The Doctrine of Deification, 277.

${ }^{276}$ Cooper, The Body in St. Maximus the Confessor, 170, 172.

277 Thumberg, The Doctrine of Deification, 432.
} 
in Maximus, one received divine revelations with boldness. ${ }^{278}$ This leads this study to question why would two ascetic theologians who, as will be revealed in the next chapter, have similar theological foundations drift so far apart on the aftermath of ascetic struggle. This question is the topic for the next chapter.

${ }^{278}$ Blowers, "Exegesis of Scripture," 267. 


\section{CHAPTER III: THE DIVERGENCE OF THEOLOGICAL THOUGHT}

While Gregory the Great's On the Song of Songs by itself was an allegorical exposition on a sensual book of the Bible and Maximus the Confessor's Letter 2: On Love was an exhortation to a fellow Christian to continue in love, read in light of each other they display a unique phenomenon in the transmission of theological ideas. Both Gregory the Great and Maximus the Confessor had similar monastic foundations and both incorporated mysticism into their monastic theology; however, they had differing thoughts on the limitations of mysticism. Putting these two texts into dialogue, this chapter argues that these works show that there was a limited transmission of theological texts across the East and West. While some ideas were adopted on both sides, the stark difference in the limitations of Christian mysticism can mainly be attributed to ideas that Gregory or Maximus used that the other theologian either did not transfer or adopt.

Both the works of Gregory the Great and Maximus the Confessor showed that the ideas of the Desert Father were transmitted to both the East and the West. The writings of the Desert Fathers formed the foundation for both theologian's ideas on Biblical exegesis and their ascetic practices. Gregory the Great's On the Song of Songs proved that the Desert Father's were borrowed in the West. As explained in the first chapter, Gregory the Great drew from Origen's Commentary on the Song of Songs for his Scriptural exegesis. The riches of knowledge contained within the bedchamber correlate with Origen's explanation of the chamber. ${ }^{279}$ Additionally, Gregory used Origen's question on why the bedchamber is called the bedchamber of the King in order to explain the need for humility when entering the bedchamber. ${ }^{280}$

\footnotetext{
${ }^{279}$ Gregory, "Commentary on the Song of Songs," 128-129. Origen, "The Commentary on the Canticle of Canticles," 84.

${ }^{280}$ Gregory, "Commentary on the Song of Songs," 129. Origen, "The Commentary on the Canticle of Canticles," 84 85.
} 
Interestingly, Gregory never openly critiqued the ideas of Origen, instead using certain interpretations and ideas in order to help frame his own.

Furthermore, the transmission of the theology of the Desert Fathers into the West can be seen with Gregory's reliance on Cassian. The writings of Cassian took the teachings that he learned in Egypt and applied it to the ascetics in France. ${ }^{281}$ In other words, Cassian brings the ideas of ascetics like Origen, Clement, and Evagrius and develops their thought, writing not for an Eastern audience, but for monks in France. ${ }^{282}$ The prominent emphasis that was put on humility in Gregory's On the Song of Songs can be traced back to the writings of Cassian. ${ }^{283}$ One example of this can be seen when Cassian wrote in The Conferences that humility is necessary for the Christian who wants to perform miracles, and thus is not given to everyone, so they do not fall in pride. ${ }^{284}$ Similarly, Gregory states not only that there are a limited amount of people that can reach the mystical bedchamber but also that humility and reverence were necessary in order for the Christian to avoid being caught up in pride. ${ }^{285}$

The transfer of the Desert Fathers to the East was also obvious in the writings of Maximus the Confessor. While Maximus spent time critiquing the problematic theology within Origen's works, he also tried to retain the ideas that were beneficial to monastic life. ${ }^{286}$ Thus, the influence of Origen's allegorical interpretation still appeared in Maximus' writings. For example, in his Letter 2:On Love, Maximus used Origen's allegorical concept of transposition in order to show that Abraham was a forerunner of the John the Cubicularius. ${ }^{287}$

\footnotetext{
${ }^{281}$ Stewart, Cassian the Monk, 18.

${ }^{282}$ Stewart, Cassian the Monk, 48.

${ }^{283}$ Demacopoulos, Gregory the Great, Kindle Location 510.

${ }^{284}$ Cassian, The Conferences, 542.

${ }^{285}$ Gregory, "Commentary on the Song of Songs," 129-130.

${ }^{286}$ Louth, "Introduction," 24-25.

${ }^{287}$ Maximus, "Letter 2: On Love," 89-90.
} 
Moreover, unlike Gregory the Great, Maximus the Confessor was directly influenced by the Greek writings of Evagrius. Maximus' stress on the importance of ascetic struggle on Christian growth and holiness originated with the writings of Evagrius. Furthermore, Maximus explained in his letter that there were negative passions, like self-love, that came from the devil. ${ }^{288}$ These ideas also originated with Evagrius and his ideas on the passions and the need for Christians to get rid of these passions. ${ }^{289}$ Thus, examining the works of Gregory the Great and Maximus the Confessor shows that the ideas of the Desert Fathers, especially of Origen and Evagrius, were transmitted to both the East and the West.

In addition to the Desert Fathers, an examination of both Gregory and Maximus' works shows that the writings and ideas of the Cappadocian Fathers had also been transferred between the East and the West. To Gregory the Great, the ideas of Gregory of Nazianzius were especially important. Through his translated works, Gregory the Great absorbed Gregory of Nazianzius's thoughts about the importance of the Church and the clergy to the salvation and growth of the congregation as a whole. ${ }^{290}$ Throughout Gregory's commentary On the Song of Songs, he comments on the importance of preachers and teachers to the salvation and growth of the believing community, especially upon new believers. ${ }^{291}$

Similarly, the works of Maximus the Confessor attest to the transmission of the Cappodocian Fathers in the East. Like Gregory the Great, Maximus the Confessor also showed that he was greatly influenced by the works of Gregory of Nazianzius. In one of his works Maximus called him a "great and wonderful teacher," showing the importance that Gregory of

\footnotetext{
${ }^{288}$ Maximus, “Letter 2: On Love," 87.

289 Plested, "The Ascetic Tradition," 166.

${ }^{290}$ Straw, Gregory the Great, 182.

${ }^{291}$ Gregory, "Commentary on the Song of Songs," 130.
} 
Nazianzius had in the eyes of Maximus the Confessor. ${ }^{292}$ As was mentioned in the previous chapter, Maximus the Confessor borrowed the terms for deification, specifically $\theta \varepsilon \varepsilon^{\prime} \omega$ and $\theta \varepsilon \dot{c} \omega \sigma \iota \varsigma$, from the writings of Gregory of Nazianzius. ${ }^{293}$ In addition to Gregory of Nazianzius, Maximus the Confessor heavily borrowed from the ideas of Gregory of Nyssa. As was seen previously, the ideas of Gregory of Nyssa helped Maximus the Confessor explain an ascetic's movement towards deification and the Eucharists role in deification. ${ }^{294}$ Thus, both Gregory the Great and Maximus the Confessor also had similar theological foundations through the influence of the Cappodician Fathers on their writings.

However, the writings of Gregory the Great and Maximus the Confessor also showed that not all theological ideas were transferred between both sides. An examination of Gregory's writing shows theological ideas by Cassian and Augustine that were not present in the works of Maximus. As mentioned above, the writings of Cassian transferred Alexandrian ideas on monasticism to the West. On the other hand, Cassian often tweaked their ideas, not including some ideas or emphasizing others. ${ }^{295}$ His emphasis on humility was probably the most obvious influence on this section of Gregory's commentary. ${ }^{296}$ These ideas influenced Gregory so much that he found pride as the greatest obstacle to Christian growth. ${ }^{297}$ Because of this, Gregory argued that the further a Christian progressed into the bedchamber, the more they ought to be brought to humility. ${ }^{298}$ Additionally, Cassian emphasized a similar theme, noting that the ascetic man would often return to carnality. ${ }^{299}$ This idea was amplified in Gregory's warning, as if

\footnotetext{
292 Louth, "Introduction," 22.

${ }^{293}$ Russell, The Doctrine of Deification, 263-264.

294 Andreopoulos, "Eschatology in Maximus the Confessor," 324, 328. Thunberg, Microcosm and Mediator, 428.

295 Stewart, Cassian the Monk, 53.

296 Demacopoulos, Gregory the Great, Kindle Location 510.

297 Demacopoulos, Gregory the Great, Kindle Location 513-514

${ }^{298}$ Gregory, "Commentary on the Song of Songs," 129.

299 Straw, Gregory the Great, 189.
} 
Gregory wanted to remind ascetics about Cassian's words in order that they might be able to faithfully enter the bedchamber.

The ideas of Cassian did not seem to transfer to the writings of Maximus the Confessor. Although Evagrius also spoke on humility, it is interesting that this emphasis on humility was emphasized in Gregory's work while being understated in Maximus' letter. While Maximus stated in the beginning of the letter that humility is important in throwing off pride, he did not mention humility again in the letter, especially not near the sections concerning deification. ${ }^{300}$ While influential to a Western audience hungry for monastic doctrine, Maximus already had the original writings of the Desert Fathers and other monastic traditions to consult, which may have made the ideas of Cassian superfluous for Maximus, if he even encountered the monastic's ideas at all.

Gregory's emphasis on humility and warning about human nature in general also showed that the ideas of Augustine were transferred and adopted by those in the West. Gregory gained not only the structure of his work but also pessimism for the state of humanity from Augustine. As was described in the first chapter, the structure and theme of the building of the church of God was similar to the Enchiridion of Augustine. The theme of faith, hope, and love leading to heavenly riches was something to which both the Enchiridion and Gregory's On Faith, Hope, and Love attested. ${ }^{301}$

Additionally, the pessimism of man's nature found within Gregory's commentary also showed the importance of Augustinian thought. Although, as seen in chapter one, Gregory transformed Augustine's ideas about original sin, Gregory nevertheless believed that man was

\footnotetext{
300 Maximus, "Letter 2: On Love," 86.

301 Augustine, The Enchiridion, 22. Gregory "Commentary on the Song of Songs," 128-129.
} 
bent towards sinful desires. ${ }^{302}$ In his Moralia, Gregory described man's weakness to sin in pathological terms, stating that Adam made the rest of the human race sick with "the infection of sin. ${ }^{״ 303}$ Carole Straw even argued that, at times, Gregory the Great emphasized the fallibility of man more than Augustine. ${ }^{304}$ Because of the dismal position of man, it makes sense that Gregory emphasized the humility found in Cassian, for it complimented his overall view of humanity and its sinful state.

On the other hand, there was little in Maximus the Confessor's work that suggested that Augustinian ideas on the theology of man and his sinfulness transferred to the Eastern Christian tradition. For a great part of his life, Maximus was exiled in North Africa and, therefore, would have had a good chance to pick up Augustinian theology. ${ }^{305}$ Because of this, many scholars have debated whether Maximus absorbed any of Augustine's thoughts. Some historians, like Andrew Louth, have been skeptical about the influence of Augustine on the ideas of Maximus while others, like George C. Berthold, argued that there were theological similarities between the two that suggest some connection. ${ }^{306}$

One 2015 study by Johannes Börjesson, focusing on Maximus' study of the will in contrast with that of Augustine, concluded that while Maximus and his disciples knew certain Augustinian texts, they had little influence on the thinking of Maximus the Confessor. ${ }^{307}$ In the article, he pointed out that Maximus mainly used Augustine when it helped support his ideas against monothelitism, but his ideas on the will developed independently of Augustine. ${ }^{308}$ At the conclusion of the study, Börjesson argued that although Maximus had heard of and read

\footnotetext{
302 Straw, Gregory the Great, 124, Demacopoulos, Gregory the Great, Kindle Location 652-653.

${ }^{303}$ Straw, Gregory the Great, 123.

304 Straw, Gregory the Great, 111.

305 Johannes Börjesson, "Augustine on the Will," in The Oxford Handbook of Maximus the Confessor ed. Pauline Allen and Bronwen Neil, (Oxford: Oxford University Press, 2015), 212.

${ }^{306}$ Börjesson, "Augustine on the Will," 212-213.

${ }^{307}$ Börjesson, "Augustine on the Will," 213.

308 Börjesson, "Augustine on the Will," 229.
} 
Augustine's works at least in part, he or his monks more likely had 'influenced' Augustinian texts through their translation and use of his works. ${ }^{309}$ This argument that the ideas of Augustine had little effect on the thinking of Maximus could also be seen in Maximus' letter. In it, there was little concern about the sinfulness of man. Instead, he emphasized the mystical union of humanity and Christ much more than Augustine ever dared to explain. Because of this textual picking and choosing, Maximus overlooked Augustine's ideas on man because they did not help support his argument against the monothelitists. Therefore, this examination of Maximus' letter supports the idea that Augustine's theological ideas had not transferred to the East in any major way before the arrival of Maximus the Confessor.

While an examination of Gregory's text reveals unique sources that were central to his thought, a similar examination of Maximus the Confessor's letter similarly reveals that he referenced a few unique sources which had not been transferred to the West. One of these theologians whose ideas were influential in the East but did not transfer to the West was PseudoDionysus. It was through his writings that Maximus the Confessor borrowed the hierarchical ideas of deification. ${ }^{310}$ As was seen in the previous chapter, Pseudo-Dionysus helped inform Maximus' idea on the importance of the community of believers to deification. ${ }^{311}$ Furthermore, Maximus' Mystagogy was replete with references and clarifications to the ideas of PseudoDionysus. ${ }^{312}$

In contrast, there was very little in Gregory's commentary to suggest that the ideas of Pseudo-Dionysus were transferred or adopted in the West. Ideas on deification in the way posited by Pseudo-Dionysus, and later Maximus the Confessor, is lacking in Gregory's On the

\footnotetext{
${ }^{309}$ Börjesson, "Augustine on the Will," 229-230.

${ }^{310}$ Louth, "Introduction," 31.

${ }^{311}$ Louth, "Introduction," 30. Maximus, "Letter 2: On Love," 88-89.

312 de Andia, "Pseudo-Dionysius the Areopagite," 190-191.
} 
Song of Songs. While Carole Straw does briefly mention that Gregory's hierarchical ordering of the universe in some of his other works "echoes" that of Pseudo-Dionysus, the main objective of the ordering of the cosmos, that of deification, was not seen in Gregory's allegory within the Song of Songs. ${ }^{313}$ The allegorical and sensual nature of this book allowed for more mystical interpretations; however, the commentary does not go into the mysticism of Pseudo-Dionysus. Instead, his mysticism echoed the more reserved ideas of the original Desert Fathers.

Additionally, an examination of Maximus' letter further reveals that ideas of Proclean Neo-Platonism were adopted by the Eastern Christian tradition, mainly through the writings of theologians like Pseudo-Dionysis, who tried to blend Neo-Platonic philosophy with Christian theology. Maximus' use of negative theology which defined God by what He is not, for instance when Maximus calls God "unfailing and unalterable," points to the transmission of Neo-Platonic ideas into theological discourse. ${ }^{314}$ Moreover, the idea that deification involved human participation was another idea that originated with Proclean Neo-Platonism and thus attested to its transmission. ${ }^{315}$

Gregory the Great, too, was influenced by Neo-Platonism, much of it gained from the writings of theologians like Ambrose. ${ }^{316}$ As was seen in the first chapter, Gregory's mystical experiences echo those described by Plotinus and Porphyry who explained that they had only one to four mystical experiences in their whole lifetime. ${ }^{317}$ Yet, Gregory only seems to adopt NeoPlatonic thought as explained by Plotinus and not that of Proclus. The bedchamber scene in his commentary points to some sort of experience between God and the ascetic. There was no reference to a union with God or take on any other deification aspects as was common in the

\footnotetext{
${ }^{313}$ Straw, Gregory the Great, 33 n23.

${ }^{314}$ Maximus, "Letter 2: On Love," 92.

${ }^{315}$ Cooper, The Body in St. Maximus the Confessor, 115.

${ }^{316}$ Straw, Gregory the Great, 13-14.

${ }^{317}$ Straw, Gregory the Great, 8.
} 
writings of Proclus. This suggests that while Neo-Platonic thought, in general, pervaded both Eastern and Western Christianity, the Proclean strain of Neo-Platonic thought solely was influential in the Eastern Roman Empire and the ideas did not transfer to the West.

This unique blend of theological influences, both shared and exclusive, led to distinctive ways in which both theologians expressed Christian mysticism. Some of these features of mysticism were similar. As seen through the two works, they both believed that asceticism could lead Christians to something greater, a supernatural experience with the divine. Gregory the Great allegorized it with the idea of the bedchamber, a place where the secrets of God penetrated the mind of the believer who happens to be shown this room by the grace of God. ${ }^{318}$ Maximus the Confessor stated that through the virtuous actions of Christians, especially that of love, they could be united with God and deified. ${ }^{319}$

Furthermore, both theologians stated that this mystical experience involved the spiritual meeting of the ascetic with Jesus Christ, one being an encounter with the beloved in the bedchamber, while the other being Christ fully enveloping the ascetic. Additionally, both agreed that it was only through God's grace and the virtuous works of the ascetic that one could ever reach this point, but some encounter with the divine was possible in some person's earthly lives. ${ }^{320}$ These emphases on the importance of asceticism to the mysticism of both theologians, the role of mysticism, and the centrality of the grace of God makes sense as both were grounded in the thought of the Desert Fathers.

However, while both theologians believed in some form of Christian mysticism, certain sources that Gregory the Great and Maximus the Confessor drew inspiration from ultimately led to differences in their interpretation of mysticism in two distinct ways: its description and

\footnotetext{
${ }^{318}$ Gregory, "Commentary on the Song of Songs," 129.

${ }^{319}$ Maximus, "Letter 2: On Love," 93.

${ }^{320}$ Gregory, "Commentary on the Song of Songs," 129. Maximus, "Letter 2: On Love," 93, 85.
} 
limitations. In the text, Gregory saw this experience as an intimate time in the bedchamber of the King, where one was able to access and know the hidden secrets and mysteries of God. ${ }^{321}$ Because of the limits of man, the mystical experience of Gregory the Great was limited as well, both being a temporary state and an incomplete picture of God. ${ }^{322}$ As seen previously, this pessimism on the state of man and the idea of limited mysticism came from a blend of Augustinian thought and the mystical beliefs of the Desert Fathers.

However, the influence of Pseudo-Dionysus and Proclus led Maximus to believe in a different type of mysticism than the one proposed by the allegory of Gregory the Great. As was seen in chapter two, Maximus believed that the ascetic life would lead some to deification. ${ }^{323}$ Maximus believed, following the theological thought of Marcarius, that through the incarnation of Christ, certain men would be able to become deified by having Christ envelop their whole being. ${ }^{324}$ While most Christians would only be able to experience this after death, certain saints and ascetics could be able to attain at least a taste of deification while in this life. ${ }^{325}$ These two ideas of Christian mysticism by Gregory the Great and Maximus the Confessor differed greatly in their description. The distinctions between the two ideas did not occur in a vacuum, but instead primarily resulted from the ideas that were central to the theology of one side but did not transfer to that of the other.

Furthermore, this document gap also led to distinctions in how Gregory and Maximus limited their mystical experience. In Gregory's allegory, the message of understanding the mysteries of Christ also came with a warning of pride and of man's sinful nature. ${ }^{326}$ As was

\footnotetext{
${ }^{321}$ Gregory, "Commentary on the Song of Songs," 129.

${ }^{322}$ McGinn, The Growth of Mysticism, 77.

${ }^{323}$ Maximus, "Letter 2: On Love," 85.

${ }^{324}$ Thunberg, Microcosm and Mediator, 431.

${ }^{325}$ Cooper, The Body in St. Maximus the Confessor, 246. Larchet, "The Mode of Deification," 348.

${ }^{326}$ Gregory, "Commentary on the Song of Songs," 129.
} 
shown in the first chapter, Gregory emphasized that man should walk into this mystical place with humility, for it was only through God's grace that one could enter this bedchamber and, even so, it could lead into prideful temptations. ${ }^{327}$ These ideas on the limitations of human nature echoed the theological thoughts of Cassian and Augustine, with their emphasis on the fallibility of man and his need for humility to avoid falling into pride.

On the other hand, Maximus the Confessor gave very little limitations to one who experiences deification in his letter. The greatest limitation he placed on deification in his letter was a brief clause only said twice explaining that it man can be deified "so far as is possible for humans. ${ }^{" 328}$ While this shows that Maximus thought that there were natural limitations to the human ascent to God, its vagueness sits in stark contrast to the warning given by Gregory the Great. Furthermore, as was noted in the previous chapter, this phrase of limitation did not originate in Christian writings but instead came from the writings of Plato. ${ }^{329}$ This, in addition to Maximus' borrowing from the writings of Pseudo-Dionysus on deification, led to the unique and continual mystical experience with the divine seen in deification.

Ultimately, these limitations also put boundaries on how far certain Christians could progress in the ascetic life. For Gregory, asceticism was something that was to be desired in both the clergy and the laity. However, the limitations Gregory put on mysticism meant that only certain people were allowed to be in the bedchamber. Only the "strong men" could understand the secrets of God, yet their accomplishment, in turn, gave hope to everyone else about their

\footnotetext{
${ }^{327}$ Gregory, "Commentary on the Song of Songs," 129.

${ }^{328}$ Maximus, "Letter 2: On Love," 93.

${ }^{329}$ Werner, Myth and Philosophy in Plato's Phaedrus, 153, 172.
} 
forgiveness of sins. ${ }^{330}$ Thus, Gregory's understanding of mysticism not only limited the experience but also limited who could experience the divine.

On the other hand, Maximus the Confessor's description of Christian mysticism made it seem more universal. Maximus, too, believed that asceticism ought to be central in the lives of Christians. Yet, unlike Gregory, Maximus stated that if one could show their perfect love through the ascetic struggle, "God takes form in each." ${ }^{331}$ There was no talk of strong or weak Christians, and, consequently, the language invoked pointed toward deification that was more or less available for all Christians willing to sacrifice themselves for the perfection of love.

As was noted throughout this examination of the similarities and differences between Gregory the Great and Maximus the Confessor, the mystical divide between these theologians can be explained by certain theological and philosophical ideas that were popular on one half of the former Roman Empire but did not get transferred to the other side. For example, while Gregory the Great absorbed the ideas of Cassian and Augustine, Maximus the Confessor was inspired by the ideas of Psuedo-Dionysus and Proclean Neo-Platonism. The ideas found within these Western and Eastern writers, respectively, did not transfer to the other tradition. Instead, by staying solely in one tradition, these ideas created obvious differences between the theological thought of Gregory and Maximus.

Furthermore, this document gap not only influenced each theologian's view on Christian mysticism but it also shaped how each saw man and his ability to succeed in the ascetic struggle. Gregory saw man pessimistically, as naturally bent towards sin and imperfect. Because Adam's sin corrupted the root of the human race, all humans have a desire for pleasure that affects not

\footnotetext{
${ }^{330}$ Gregory, "Commentary on the Song of Songs," 130.

${ }^{331}$ Maximus, "Letter 2: On Love," 90.
} 
only their conscious mind but also their subconscious thoughts. ${ }^{332}$ For this reason, although one might grow in holiness through rigorous ascetic practice, there were always temptations which could cause even the best saint to stumble. ${ }^{333}$ As Carole Straw points out, blessings that God gives to those in the contemplative life can be corrupted by the sinful desires of pride. ${ }^{334}$ Thus, at the same time as Gregory declared the benefits of virtuous living in this section on the Song of Songs, he also warned his readers of the sinful temptations that could come from this blessing. In this way, he acted both as interpreter and pastor, both opening up the deeper meaning of the Biblical passage to his audience and yet shepherding his flock by warning them about the dangers that lurk along the mystical path.

In contrast, Maximus the Confessor was more optimistic on the human ability to overcome sin through the grace of God while still living on the earth. Maximus admitted, and even stressed, that the ascetic life is a struggle, stating that all the saints must constantly battle sinfulness and resist death. ${ }^{335}$ However, his repetition that one's good works could lead to a person's deification points to Maximus' optimism that John and the other readers could reach this mystical experience. ${ }^{336}$

Ultimately, Maximus believed that humanity, because of the death and resurrection of Christ, had the "free will" to choose vice or virtue in their personal lives. ${ }^{337}$ While this did give humanity the freedom to choose damnation by pursuing vice over virtue, it also allowed the possibility that certain men in this life might be able to overcome sin through their constant

\footnotetext{
332 Straw, Gregory the Great, 122.

333 Straw, Gregory the Great, 103, 242.

334 Straw, Gregory the Great, 259.

${ }^{335}$ Maximus, "Letter 2: On Love," 91.

336 Maximus, "Letter 2: On Love," 93.

${ }^{337}$ Bronwen Neil, "Divine Providence and the Gnomic Will Before Maximus," in The Oxford Handbook of Maximus the Confessor ed. Pauline Allen and Bronwen Neil, (Oxford: Oxford University Press, 2015 ), 245.
} 
choice of virtue. ${ }^{338}$ In contrast to Gregory, Maximus stated that those who are worthy of God have already put away pride and self-love, as this is the beginning evil, and because of this are able to virtuously act for Christ. ${ }^{339}$ However, after overcoming pride, there is no warning of relapse, instead Maximus only explained how one might advance in the faith towards the goal of deification.

So far, this chapter has examined the theological foundations of Maximus and Gregory, examined how their theological differences led to divisions in their theological thought concerning Christian mysticism, and how these differences also influenced each theologian's perception of man's ability to overcome sin in this life. This next section will examine why this gap in theological understanding occurred. To understand what caused this division in the theological thought of Gregory the Great and Maximus the Confessor, one must further examine the background circumstances of these theologians. Of utmost importance are the ways these circumstances affected the transmission of theological ideas over time. While there are many things that could account for this split during this time period there are two major obstacles that kept one from adopting the ideas of the other and vice versa: language and theological controversies.

The difference of language overtime became a barrier for Christians communicating around the Mediterranean to overcome. This was true for Gregory the Great. While Gregory read, knew, and sometime quoted from the works of the Desert Fathers and the Cappadocian Fathers, he only knew them in translation. ${ }^{340}$ Furthermore, when Gregory was called to be a representative of the papacy in Constantinople, he lived not with the Greek monastics but instead

\footnotetext{
338 Neil, "Divine Providence and the Gnomic Will," 245

${ }^{339}$ Maximus, "Letter 2: On Love," 88.

340 Straw, Gregory the Great, 13.
} 
took fellow brothers from his own monastery to live with him in the second Rome. ${ }^{341}$ Even in his epistolary communications with bishops in the Eastern Roman Empire, Gregory complained that there were no decent translators of Greek in the area. ${ }^{342}$ Since Gregory did not know Greek, the writings of some Eastern theologians and philosophers would not have been available to Gregory, especially if they were relatively new ideas.

Similarly, Maximus the Confessor likely could not read Latin. There are no sources that directly explain if he had any knowledge of Latin and, consequently most scholars have had to speculate on this conundrum. ${ }^{343}$ However, the study by Johannes Börjesson suggested that Maximus did not have a strong command of the Latin language. Maximus once stated "I love the Romans because we share the same faith, whereas I love the Greeks because we share the same language." ${ }^{344}$ This attested to the fact that while living in North Africa, Maximus mainly spent time with monastics who spoke Greek, not with those who spoke Latin. ${ }^{345}$ Therefore, Maximus did not have easy access to the writings of Western authors including Augustine, Ambrose, and Cassian, who were central to the theology of Gregory the Great. Additionally, Maximus and his monks had to translate Augustine while in North Africa, suggesting that there had not been any previous attempts to translate Augustine's works into Greek. ${ }^{346}$ Because of this language barrier, unique theological ideas were able to develop in the East and West independently of each other.

The problem with language also explained why both Maximus the Confessor and Gregory the Great had similar foundations in the Desert and Cappadocian Fathers. Both of these

\footnotetext{
${ }^{341}$ Robert Austin Markus, Gregory the Great and His World, (Cambridge: Cambridge University Press, 1999$), 10$.

342 John Moorhead, "Western Approaches (500-600)," in The Cambridge History of the Byzantine Empire, ed. Jonathan Shepard (Cambridge: Cambridge University Press, 2008), 220.

${ }^{343}$ Brian E. Daley, "Making a Human Will Divine: Augustine and Maximus on Christ and Human Salvation," in Orthodox Readings of Augustine, ed. George E. Demacopoulos and Aristotle Papanikolaou, (Crestwood, NY: St. Vladmir's Eminary Press, 2008), 102.

344 Börjesson, "Augustine on the Will," 228.

345 Börjesson, "Augustine on the Will," 228.

${ }^{346}$ Börjesson, "Augustine on the Will," 229-230.
} 
sources were already in the Greek and thus easily accessible to Maximus the Confessor. On the other side, these ideas were later passed down to the West either through translations, like Jerome and Rufinus did for Origen, or by Western ascetics gaining the wisdom of the East and bringing it to be practiced in the West, best illustrated in the works of Cassian. The works of the Cappadocian Fathers were also translated into Latin, allowing Gregory to also take ideas from these theologians. ${ }^{347}$ Thus, language limited the theological knowledge of both writers. Since both Gregory and Maximus only mastered their native tongue, it narrowed the authors that each person could read.

Furthermore, Gregory the Great and Maximus the Confessor had to deal with unique crises on which they concentrated their studies. Gregory the Great was focused on protecting Rome from the constant invasion of the Lombards, organizing the military of Rome and supplying them with the resources they needed. ${ }^{348}$ Additionally, he administrated not only papal estates which were commercially farmed for the benefit of the Church, but also churches around the former Western Roman Empire. ${ }^{349}$ The over eight hundred and fifty letters that Gregory wrote attested to this fact. ${ }^{350}$ Moreover, Gregory the Great had his own theological controversies to confront. He had disagreements with Eastern theology that kept him from adopting certain theological ideas. This was very obvious during his stay in Constantinople, where Gregory disagreed with the city's patriarch, Eutychius, over the resurrection of the body of Christ, ultimately defending his reasoning with Western theological sources. ${ }^{351}$ While bishop of Rome, he also had to confront the heresy of Arianism practiced by some "barbarian" rulers.

\footnotetext{
347 Straw, Gregory the Great, 13.

348 DelCogliano, "Introduction," 17.

349 DelCogliano, "Introduction," 18.

350 Straw, Gregory the Great, 6.

${ }^{351}$ Markus, Gregory the Great and His World, 11.
} 
Furthermore, paganism was still prevalent outside of the Mediterranean which ultimately pushed Gregory to send out missionaries to places like Britain.

Additionally, with this area becoming only a small vestige of its former imperial glory, plagues devastating the population, and the migrating Lombard tribes enclosing the city of Rome, to many it seemed like the end of days. Thus, Gregory focused on preparing the Church for Jesus' coming. He advocated for monasticism as the highest form of Christianity, which could be seen when reading his On the Song of Songs as he praised asceticism and its terminology of contemplation and compunction. ${ }^{352}$ Furthermore, Gregory wrote about the importance of the Church and their leaders in his Pastoral Rule. ${ }^{353}$ He also tried to combat the corruption he was seeing in the Church, especially by priests and bishops. ${ }^{354}$

Because of his enthusiasm for the monastic life, the Desert Fathers were central to his theological thought. Additionally, because he viewed active ministry in addition to contemplation as important to the life of a minister, the Cappadocian Fathers were invaluable to his theology for both Gregory Nazianzian and Basil wrote on the importance of spiritual leaders to leave contemplation for the active life. ${ }^{355}$ These issues, together with his lack of knowledge in Greek, give a fuller picture as to why these ideas that were central to the theological thought of Maximus the Confessor were not adopted by Gregory the Great.

On the other hand, Maximus the Confessor focused his efforts in North Africa on combating the Christological heresy of monothelitism, the belief that Jesus had only one will during His life on Earth. ${ }^{356}$ This belief, while not prevalent in the West, was influential throughout the Eastern Roman Empire as it was propagated by both church officials and imperial

\footnotetext{
${ }^{352}$ DelCogliano, "Introduction," 20.

${ }^{353}$ DelCogliano, "Introduction," 22.

${ }^{354}$ Straw, Gregory the Great, 5.

${ }^{355}$ Demacopoulos, Gregory the Great, Kindle Location 1026.

356 Börjesson, "Augustine on the Will," 229.
} 
authority in Constantinople. ${ }^{357}$ Consequently, much of Maximus's writing is focused on defending the dyothelite will of Christ, or in other words, how Jesus had not only a divine will but also a human will. Because of his confession of the two wills of Christ and being exiled for these beliefs, Maximus was called, "the Confessor." 358

However, since Maximus focused of the majority of his theological writings on this controversy, he mainly used and cited Western sources when they helped support his argument on Christ's dyothelite will. ${ }^{359}$ Consequently, major ideas of Augustine's, or of any other Western theologian, were selectively chosen as Maximus tried to find theological support against monothelitism in order to successfully argue against the churches, clergy, and imperial authority who were spreading what he thought was heresy in the Eastern Roman Empire.

These issues that Gregory the Great and Maximus the Confessor dealt with narrowed the research that either theologian could have done on the overall thinking of the other side. This combined with the lack of language understanding led to a further restriction of the transmission of theological texts and ideas. Because there was no official theological conflict over mysticism, there was no reason for Gregory the Great to find, translate, and critique the writings in the East. Gregory's possible ignorance to new ideas coming out of the Eastern churches is exacerbated by the fact that when Gregory was a papal ambassador to Constantinople he thought many of the religious leaders in the church were heretics. ${ }^{360}$ Even after becoming pope of the Catholic Church, the combination of the conflict with the Lombards, extensive writing projects, and the administration of papal lands and issues dealing with churches, preoccupied his time when he became pope.

\footnotetext{
${ }^{357}$ Louth, "Introduction," 48.

${ }^{358}$ Louth, "Introduction," 48.

359 Börjesson, "Augustine on the Will," 229.

${ }^{360}$ John Moorhead, The Popes and the Church of Rome in Late Antiquity (New York: Routledge, 2015$), 132$.
} 
Similarly, because Maximus the Confessor was focused on the monothelite controversy in the Eastern Roman Empire, he had very little reason to examine find, translate, and critique Western theologians unless it dealt specifically with countering the theological claims of monothelitism. While he had a more amicable view of Western theology than that of Gregory on Eastern theology, many of his theological views had been cemented before arriving in North Africa. ${ }^{361}$ However, these ideas on man and Christian mysticism would have profound effects on both Eastern and Western holy men and how these theological issues affected their social reality.

${ }^{361}$ Börjesson, "Augustine on the Will,” 229. 


\section{CONCLUSION: WHY THEOLOGY MATTERS}

In the past three chapters, two examples of Christian mysticism have been explored. The first chapter examined Gregory the Great's On the Song of Songs, and showed the ascent via faith, hope, and love to the bedroom of the King. ${ }^{362}$ In this allegory, Gregory the Great looked towards the mysticism of the East while putting these ideas in the framework of Western theology. Thus, he was able to blend the thoughts of Origen and the Cappadocian Fathers with doctrine emphasized by Cassian and Augustine. The second chapter observed Maximus the Confessor's Letter 2: On Love. His work explained that faith and hope lead to love and that the perfection of love leads to deification. ${ }^{363}$ Maximus heavily incorporated Proclean Neo-Platonist and Pseudo-Dionysian ideas into his theological worldview leading to a view of deification which emphasized God's inhabiting humanity. The third chapter put the writings of Maximus and Gregory into dialogue with each other, showing that although they shared a similar ascetic foundation, they also drew from unique theologians that shaped the expansion and limits of each theologian's mysticism. While this information is interesting in itself, how can these distinctions that this study has found between Christian mysticism of Maximus and Gregory connect with greater themes of Late Antique history and Christianity in general? This final section of the study will apply the information from the previous chapters in order to get a better understanding of the theological place of the holy man of Late Antiquity.

In 1971, Peter Brown wrote an article examining the lives of certain ascetics in Late Antiquity called "The Rise and Function of the Holy Man in Late Antiquity." In the article, Brown explains how holy men rose out of Syria and Asia Minor in the fourth and fifth centuries

\footnotetext{
362 Gregory, "Commentary on the Song of Songs," 128.

${ }^{363}$ Maximus, "Letter 2: On Love," 86-87.
} 
and became major influencers in Byzantine society. ${ }^{364}$ Because of the geographical location of the holy man between the desert and society and the role he filled as a political and religious mediator in mountain villages that were in want of leadership, the reverence of the holy man grew in Byzantium. ${ }^{365}$ Later in the article, Brown argued that the place of spiritual power in Byzantine society and Western Europe differed. ${ }^{366}$ In Western Europe, the relics of dead martyrs and other important figures in the Church held the greatest spiritual power along with the clergy that looked over these relics. ${ }^{367}$ On the other hand, spiritual power in Byzantium was located not in a central place but among holy men in the area and their actions within society. ${ }^{368}$

However, while Brown expounded on the Syrian holy man and his interaction with the local community, pointing out a major distinction between the West and the East in terms of holy men, he never gave any theological reason as to this distinction. Near the end of the article he stated that holy men took on the role of oracles, leading to the decline in the popularity and eventual silence of oracles like the one at Delphi. ${ }^{369}$ Additionally, he made some good social observations as to why the villagers preferred the holy man, showing that people in the villages would favor the holy man because of his corporality and how he fit with an increasingly personal society. ${ }^{370}$ Yet Brown did not show how these holy men used theology in order to justify their own existence. Instead, Brown took for granted Christianity's allowance for both the rise of holy men and the importance of relics, while not asking what makes their actions theologically acceptable and distinct in Western and Eastern Christianity. Some might argue that during the Late Antique period there were many different types of Christianity that were being practiced so

\footnotetext{
364 Brown, "The Rise and Function," 91.

365 Brown, "The Rise and Function," 83, 85.

366 Brown, "The Rise and Function," 95.

${ }^{367}$ Brown, "The Rise and Function," 95

368 Brown, "The Rise and Function," 95-6.

369 Brown, "The Rise and Function," 99-100

${ }^{370}$ Brown, "The Rise and Function," 100.
} 
what is the point of this theological inquiry? The answer is that while there were many types of Christianity being practiced, they all had theological ideas that were based on the combination of Biblical and patristic sources. If one does not know the foundation of one sect of Christianity's thought, then one is missing an important key in understanding how theology affects other parts of human society.

Thus, it is concerning this question that understanding the theology of Maximus the Confessor and Gregory the Great becomes particularly useful. Maximus the Confessor's theology holds the key as to why holy men could be revered in Byzantine society, especially around Syria: deification. One theologian from whom Maximus the Confessor most heavily drew his theology on deification was Pseudo-Dionysus. ${ }^{371}$ Coincidentally, research has pointed that Pseudo-Dionysus probably was a monk who lived in Syria. ${ }^{372}$ Also, as seen in the third chapter, Maximus did not exclude people from the mystical experience, but said that God inhabited those who are able to perfect love. Furthermore, as was seen in the second chapter, Maximus believed that deification gave certain people the ability to take on the tropos of God, allowing them to put on the wisdom of mankind and spiritually mediate between God and man. ${ }^{373}$ Because they were deified, thus, they could act as a place of meeting between humanity and the divine. ${ }^{374}$

These descriptions of the deified man nearly echo the descriptions of the role of the holy man in Brown's work. Brown referred to the holy man as the "God-bearing man" and regularly pointed to him as an "arbitrator and mediator." 375 Interestingly, Brown stated that "the distinctive feature of the Late Roman holy man is that he gained the position of a stranger among

\footnotetext{
${ }^{371}$ Louth, "Introduction," 28-30.

372 Louth, "Introduction," 29.

${ }^{373}$ Larchet, "The Mode of Deification," 342, 347-348. Russell, The Doctrine of Deification, 277.

${ }^{374}$ Cooper, The Body in St. Maximus the Confessor, 170, 172.

375 Brown, "The Rise and Function," 88, 95
} 
men without being possessed by a god." ${ }^{376}$ However, this study has shown that this claim might not totally be true. Deified man was constantly being penetrated by the divine, becoming "what God is by essence." ${ }^{377}$ Thus, by applying the theology of Maximus the Confessor, one can understand the theological reasoning as to why a holy man could step into the realm of mediator. Because of the doctrine of deification, Christian holy men emerged in areas like Syria and rose through contemplation in the desert. Afterwards the holy man could return to the mountain villages as a mediator between God and man, having the tropos of God.

Furthermore, this study can also help understand the theological reason for the reverence of saint's relics in the West in contrast to the living holy men of the East. As noted above, Brown argued that these distinctions were a product of a debate of where spiritual power was located. ${ }^{378}$ However, part of the reason for this divergence in the rise of the holy man was in the limitations of mysticism. While Maximus the Confessor in the East believed that man could become deified through the perfection of love, this was far from the mind of Gregory the Great in the West. Gregory stated that while certain men were able to reach a mystical place in their spiritual walk as allegorized by the bedchamber, these people needed to approach this area with humility. ${ }^{379}$ Moreover, nowhere in this work are those who have reached the bedchamber equated to God. Instead, Gregory told those who reached this chamber to remember that they are human and that they should not exalt themselves. ${ }^{380}$ Instead, man must continually atone for their sinfulness to maintain their relation with God. ${ }^{381}$ This sinful nature would not be taken away until after the person died and were taken to heaven. In fact, during this life, Gregory extolled Christians to

\footnotetext{
376 Brown, "The Rise and Function," 93.

377 Thunberg, Microcosm and Mediator, 431. Russell, The Doctrine of Deification, 266.

378 Brown, "The Rise and Function," 95.

379 Gregory, "Commentary on the Song of Songs," 129.

380 Gregory, "Commentary on the Song of Songs," 129-30.

381 Straw, Gregory the Great, 221-222.
} 
constantly be on guard because their sins could lead them to turn away from God and become one of the "horses of Pharaoh." 382

Because of this, the only way one would fully know if someone was truly a saint of God was after their death. When a holy man passed on from death to new life, their soul continued to animate the relics and the corpse of the holy man, allowing the saint to show the true power of heaven. ${ }^{383}$ This kind of power in the relics did not only reassure pilgrims that this holy man was with God both during his life and now even more so after death, but it also gave them a glimpse of the "fullness of life" that heaven offered. ${ }^{384}$ Because of both the theological uncertainty of the holiness of man in life and the power of relics which confirmed the power of holy men after death, spiritual power in the West drifted towards the reverence of relics instead of living holy men.

Thus, it can be seen that the further study of theological ideas concerning mysticism and humanity can help historians better understand the difference in the Christianities of Late Antiquity and how they influenced their society. It is very important that historians examine the social and cultural history of a time period to see how people adapted to a rapidly changing world, especially during the tumultuous era that was Late Antiquity. However, understanding some of the whys to historical research cannot be understood without getting into the thoughts and beliefs of people during the time period. Bryan Ward-Perkins, in his 2005 monograph The Fall of Rome and the End of Civilization, said that he was mystified as to why Late Antique historians are so intrigued in the history of religion during this time period. ${ }^{385}$ Religion is important to the understanding of Late Antiquity because by understanding the theology of the

\footnotetext{
382 Gregory, "Commentary on the Song of Songs," 143.

383 Straw, Gregory the Great, 56-57.

384 Straw, Gregory the Great, 56.

385 Ward-Perkins, The Fall of Rome, 180.
} 
Late Antique people, historians can better grasp their worldview and how they responded to adverse times. This can be shown in Ward-Perkins' own monograph, where he examined how Christian theologians reacted to the invasions by barbarian tribes. ${ }^{386}$ In so doing, Ward-Perkins showed why Late Antique historians are fascinated with the study of religion. Both his description and this study shows that the similarities and differences found in Christianity during this time period helped shape the thought, reactions, and writings of those people.

This study also points out that there was no one Christian Church with a unified doctrine during Late Antiquity. Although this idea is mundane for historians of the Late Antique Church, this is a common misconception in popular and religious culture. In a 2006 book by Tom Streeter on church history, he described that the Church, though fret with conflict, was a "unified institution" until the Great Schism of $1054 .{ }^{387}$ Christian narratives about church history, from not only the Catholic Church but also in Protestant denominations, claim that the church had been unified until the Great Schism of 1054. Studies like this one on Gregory the Great and Maximus the Confessor show that there are some theological constants between the thinking of Gregory and Maximus, like the use of 1 Corinthians 13 and the importance of the Desert Fathers. However, their ideas on Christian mysticism were very different. They drew from different sources and arrived to different conclusions on how close man could come to God during this life. These writings, along with the unique sources that each theologian used, show that Christianity was not fully unified in doctrine during this time.

This study, ultimately, is an attempt to bring the Greek East and Latin West into dialogue with each other. By examining the works of Gregory the Great and Maximus the Confessor, it has attempted to understand what ideas were influential to each theologian and how they used

\footnotetext{
${ }^{386}$ Ward-Perkins, The Fall of Rome, 29.

387 Tom Streeter, The Church and Western Culture: An Introduction to Church History, (Bloomington, IN: Booktango, 2012) 158.
} 
these ideas in their work. This study also tried to distinguish what ideas were shared among the traditions, which were unique to each tradition, and why these distinctions occurred. Finally, it has attempted to show the importance of understanding these differences both in the study of Christian mysticism and in historical study in general. Hopefully this study serves a bigger purpose and encourages other historians to examine this interesting time period and to help us better understand the complex time that was Late Antiquity. 


\section{BIBLIOGRAPHY}

\section{PRIMARY SOURCES}

Augustine. The Enchiridion, edited by Paul A. Böer, translated by Sr. J.F. Shaw. Veritatis Splendor Publications, 2012.

Cassian, John. The Conferences, translated by Boniface Ramsey. New York: Newman Press, 1997.

Gregory the Great. "Commentary on the Song of Songs." In Gregory the Great: On the Song of Songs, edited and translated by Mark DelCogliano, 107-144. Collegeville, MN: Cistercian Publications, 2012.

Maximus the Confessor. "Difficulty 10." In Maximus the Confessor, translated and edited by Andrew Louth, 94-154. New York: Routledge, 2006.

----. “Letter 2: On Love.” In Maximus the Confessor, translated and edited by Andrew Louth, 8593. New York: Routledge, 2006.

Origen. "The Commentary on the Canticle of Canticles." In Ancient Christian Writers: The Works of the Fathers in Translation, edited by Johannes Quasten and Joseph C. Plumpe, translated by R. P. Lawson, 21-306. Westminster, MD: The Newman Press, 1957.

\section{SECONDARY SOURCES}

Allen, Pauline. "Life and Times of Maximus the Confessor." In The Oxford Handbook of Maximus the Confessor, edited by Pauline Allen and Bronwen Neil, 3-18. Oxford: Oxford University Press, 2015.

de Andia, Ysabel. "Pseudo-Dionysius the Areopagite and Maximus the Confessor." In The Oxford Handbook of Maximus the Confessor, edited by Pauline Allen and Bronwen Neil, 177-193. Oxford: Oxford University Press, 2015. 
Andreopoulos, Andreas. "Eschatology in Maximus the Confessor." In The Oxford Handbook of Maximus the Confessor, edited by Pauline Allen and Bronwen Neil, 322-340. Oxford: Oxford University Press, 2015.

Blowers, Paul M. Exegesis and Spiritual Pedagogy in Maximus the Confessor: An Investigation of the "Quaestiones ad Thalassium." Notre Dame, IN: University of Notre Dame Press, 1991.

----. "Exegesis of Scripture.” In The Oxford Handbook of Maximus the Confessor, edited by Pauline Allen and Bronwen Neil, 253-273. Oxford: Oxford University Press, 2015. Booth, Phil. "Gregory the Great and the Greek East." In A Companion to Gregory the Great, edited by Bronwen Neil and Matthew J. Del Santo, 109-134. Leiden, Netherlands: Koninklijke Brill NV, 2013.

Börjesson, Johannes. “Augustine on the Will.” In The Oxford Handbook of Maximus the Confessor, edited by Pauline Allen and Bronwen Neil, 212-234. Oxford: Oxford University Press, 2015.

Brown, Peter. "The Rise and Function of the Holy Man in Late Antiquity." The Journal of Roman Studies 61 (1971), 80-101.

----. The Rise of Western Christendom. Malden, MA: Blackwell Publishing, 2003.

----. Society and the Holy in Late Antiquity. Berkeley, CA: University of California Press, 1982. Cattoi, Thomas. "Liturgy as Cosmic Transformations." In The Oxford Handbook of Maximus the Confessor, edited by Pauline Allen and Bronwen Neil, 414-438. Oxford: Oxford University Press, 2015.

Cooper, Adam G. The Body in St. Maximus the Confessor: Holy Flesh, Wholly Deified, (Oxford: Oxford University Press, 2005. 
Daley, Brian E. "Making a Human Will Divine: Augustine and Maximus on Christ and Human Salvation.” In Orthodox Readings of Augustine, edited by George E. Demacopoulos and Aristotle Papanikolaou, 101-126. Crestwood, NY: St. Vladmir's Eminary Press, 2008. DelCogliano, Mark. "Introduction." In Gregory the Great: On the Song of Songs, edited by Mark DelCogliano, 1-102. Collegeville, MN: Cistercian Publications, 2012.

Del Santo, Matthew. "Gregory the Great and Eustratius of Constantinople: The Dialogues on the Miracles of the Italian Fathers as an Apology for the Cult of the Saints." Journal of Early Christian Studies 17, no 3 (Fall 2009), 421-457.

Demacopoulos, George E. Gregory the Great: Ascetic, Pastor, and First Man of Rome. Kindle Edition. Notre Dame, IN: University of Notre Dame Press, 2015.

----. The Invention of Peter: Apostolic Discourse and Papal Authority in Late Antiquity. Philadelphia: University of Pennsylvania Press, 2013.

Dudden, F. Homes. Gregory the Great: His Place in History and Thought Volume Two. London: Longmans, Green, and Co., 1905.

Heather, Peter. Empires and Barbarians: The Fall of Rome and the Birth of Europe. Oxford: Oxford University Press, 2009.

Hollywood, Amy. "Introduction.” In The Cambridge Companion to Christian Mysticism, edited by Amy Hollywood and Patricia Z. Beckman, 1-36. Cambridge: Cambridge University Press, 2012.

Jankowiak, Marek and Phil Booth. "A New Date-List of the Works of Maximus the Confessor." In The Oxford Handbook of Maximus the Confessor, edited by Pauline Allen and Bronwen Neil, 19-83. Oxford: Oxford University Press, 2015. 
Larchet, Jean-Claude. "The Mode of Deification." In The Oxford Handbook of Maximus the Confessor, edited by Pauline Allen and Bronwen Neil, 341-359. Oxford: Oxford University Press, 2015.

Lollar, Joshua. "Reception of Maximian Thought in the Modern Era." In The Oxford Handbook of Maximus the Confessor, edited by Pauline Allen and Bronwen Neil, 564-580. Oxford: Oxford University Press, 2015.

Louth, Andrew. "Christology and Heresy." In A Companion to Byzantium, edited by Liz James, 187-198. Malden, MA: Blackwell Publishing, 2010.

----. "Introduction." In Maximus the Confessor, edited by Andrew Louth, 3-77. New York: Routledge, 2006.

---.. "Introdction to 'Letter 2: On Love."” In Maximus the Confessor edited by Andrew Louth , 84-85. London: Routledge, 1996.

De Lubac, Henri. Medieval Exegesis Vol I: The Four Senses of Scripture, translated by Mark Sebanc. Grand Rapids, MI: Willian B. Eerdmans Publishing Company, 1998.

Markus, Austin. Gregory the Great and His World. Cambridge: Cambridge University Press, 1999.

Matter, E. Ann. The Voice of My Beloved: The Song of Songs in Western Medieval Christianity. Philadelphia: University of Philadelphia Press, 1992.

McGinn, Bernard. The Growth of Mysticism: Gregory the Great to the $12^{\text {th }}$ Century. New York: The Crossroad Publishing Company, 1994.

Meyendorff, John. Byzantine Theology. New York: Fordham University Press, 1974. Moorhead, John. The Popes and the Church of Rome in Late Antiquity. New York: Routledge, 2015. 
----. "Western Approaches (500-600)." In The Cambridge History of the Byzantine Empire, edited by Jonathan Shepard, 196-220. Cambridge: Cambridge University Press, 2008.

Neil, Bronwen. "Divine Providence and the Gnomic Will Before Maximus." In The Oxford Handbook of Maximus the Confessor, edited by Pauline Allen and Bronwen Neil, 235252. Oxford: Oxford University Press, 2015).

Petersen, Joan M. "The Influence of Origen Upon Gregory the Great's Exegesis." Studia Patristica 17 (1985): 343-347.

Plested, Marcus. "The Ascetic Tradition." In The Oxford Handbook of Maximus the Confessor, edited by Pauline Allen and Bronwen Neil, 164-176. Oxford: Oxford University Press, 2015.

Remes, Pauliina. Neoplatonism. Berkley, CA: University of California Press, 2008.

Russell, Norman. The Doctrine of Deification in the Greek Patristic Tradition. Oxford: Oxford University Press, 2006.

Smalley, Beryl. The Study of the Bible in the Middle Ages. Notre Dame, IN: Notre Dame University Press, 1978.

Stewart, Columbia. Cassian the Monk. Oxford: Oxford University Press, 1998.

Straw, Carole. Gregory the Great: Perfection in Imperfection. Berkeley: University of California Press, 1988.

Streeter, Tom. The Church and Western Culture: An Introduction to Church History. Bloomington, IN: Booktango, 2012.

Thunberg, Lars. Microcosm and Mediator: The Theological Anthropology of Maximus the Confessor. Chicago: Open Court Publishing Company, 1995. 
Tollefsen, Torstein T. "Christocentric Cosmology." In The Oxford Handbook of Maximus the Confessor, edited by Pauline Allen and Bronwen Neil, 307-321. Oxford: Oxford University Press, 2015.

Ward-Perkins, Bryan. The Fall of Rome and the End of Civilization. Oxford: Oxford University Press, 2006.

Werner, Daniel S. Myth and Philosophy in Plato's Phaedrus. Cambridge: Cambridge University Press, 2012. 